\title{
Roken in Nederland : de keerzijde van tolerantie
}

\author{
Citation for published version (APA):
}

Willemsen, M. (2011). Roken in Nederland : de keerzijde van tolerantie. Maastricht University. https://doi.org/10.26481/spe.20110114mw

Document status and date:

Published: 14/01/2011

DOI:

10.26481/spe.20110114mw

Document Version:

Publisher's PDF, also known as Version of record

\section{Please check the document version of this publication:}

- A submitted manuscript is the version of the article upon submission and before peer-review. There can be important differences between the submitted version and the official published version of record.

People interested in the research are advised to contact the author for the final version of the publication, or visit the DOI to the publisher's website.

- The final author version and the galley proof are versions of the publication after peer review.

- The final published version features the final layout of the paper including the volume, issue and page numbers.

Link to publication

\footnotetext{
General rights rights.

- You may freely distribute the URL identifying the publication in the public portal. please follow below link for the End User Agreement:

www.umlib.nl/taverne-license

Take down policy

If you believe that this document breaches copyright please contact us at:

repository@maastrichtuniversity.nl

providing details and we will investigate your claim.
}

Copyright and moral rights for the publications made accessible in the public portal are retained by the authors and/or other copyright owners and it is a condition of accessing publications that users recognise and abide by the legal requirements associated with these

- Users may download and print one copy of any publication from the public portal for the purpose of private study or research.

- You may not further distribute the material or use it for any profit-making activity or commercial gain

If the publication is distributed under the terms of Article $25 \mathrm{fa}$ of the Dutch Copyright Act, indicated by the "Taverne" license above, 


\section{Maastricht University}

\section{Prof. dr. Marc Willemsen}

Faculty of Health, Medicine and Life Sciences

\section{Roken in Nederland \\ De keerzijde van tolerantie}

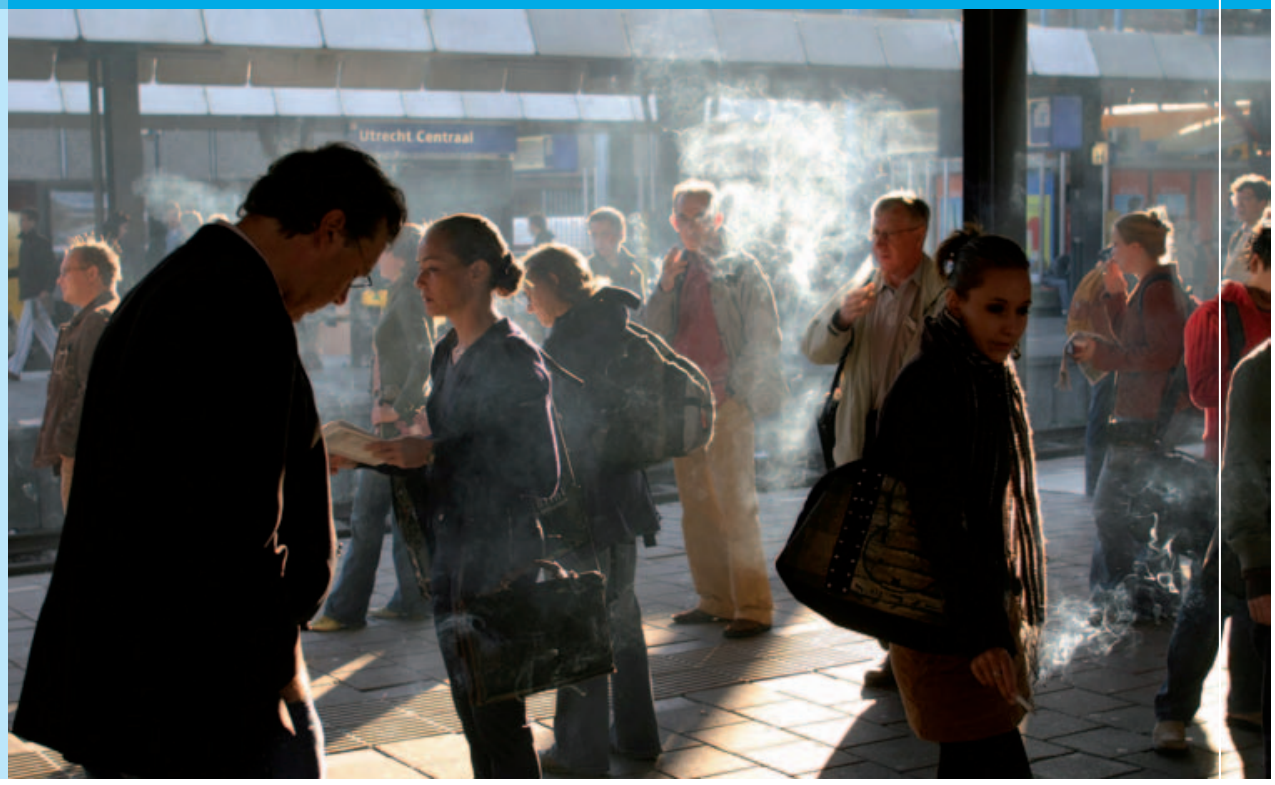


Roken in Nederland

De keerzijde van tolerantie 


\section{Colofon}

Ontwerp en print: Océ Business Services, Maastricht

Coverfoto: Bert Verhoeff/HH

ISBN: 978-90-5681-354-3

NUR: 870

Alle rechten voorbehouden. Niets uit deze uitgave mag worden verveelvoudigd, opgeslagen in een geautomatiseerd gegevensbestand of openbaar gemaakt worden, zonder voorafgaande schriftelijke toestemming van de auteur of uitgever. 


\section{Roken in Nederland De keerzijde van tolerantie}

Oratie

Maastricht, 14 januari 2011

Door Prof. dr. Marc Willemsen 
Mijnheer de Rector, geachte collega's, beste familie en vrienden,

Stel dat er een product op de markt zou worden toegelaten dat voor vrijwel iedereen direct verslavend is en dat mensen ernstig ziek zou maken als ze het gebruiken precies op de manier zoals de fabrikant het product ontworpen en bedoeld heeft. Stel dat dit product in de supermarkt zou komen te liggen. Dat zou toch beslist ondenkbaar zijn? Toch ligt er precies zo'n product in de supermarkten. Dat is tabak, in honderden varianten en verschijningsvormen. Tabak wordt wel beschouwd als het dodelijkste consumentenproduct dat ooit is ontwikkeld en is desondanks volstrekt legaal. Deze historische anomalie kon ontstaan, omdat sigaretten, toen ze op de markt kwamen, nog niet in verband werden gebracht met verslaving en ziekte. De eerste wetenschappelijke rapporten hierover die in brede kring serieus werden genomen, verschenen pas in de jaren '60, maar toen was het al te laat. Geholpen door intensieve reclamecampagnes en de uitvinding van machines waarmee sigaretten in massale hoeveelheden konden worden gefabriceerd, werd het roken razendsnel een onlosmakelijk onderdeel van de Westerse cultuur. Het hoogtepunt van de sigarettenconsumptie lag in de jaren '50 en ' 60 . Toen rookte meer dan de helft van de bevolking en in de hogere lagen van de samenleving rookten bijna alle mannen. TV-series als 'Mad Men' en 'Annie MG' laten zien hoe dat er in de jaren '60 en '70 uitzag. Nu komen de beelden uit dit soort series over als vreemd, maar ze reflecteren gewoon de realiteit van toen. Roken was nog heel gewoon en de vraag 'mag ik hier roken?' werd niet gesteld. Ik ben zelf ook tussen rookwolken opgegroeid. Nooit iets vreemds aan gevonden, toen.

Tegenwoordig is dat heel anders. Het bewustzijn dat roken slecht is voor de gezondheid, heeft het positieve imago van roken verstoord. De samenleving heeft tegenwoordig een haat-liefde verhouding met de sigaret. We tolereren het als een consumentenproduct, niet alleen omdat het een legaal product is, maar ook omdat sigaretten geen direct waarneembare ontwrichtende gevolgen hebben. De meeste mensen zijn er ook niet écht bang voor, omdat de schadelijke gevolgen pas na ongeveer 30 jaar intensief gebruik optreden. Wie dan leeft die dan zorgt. En voor sommigen, vooral jongeren, kan het aantrekkelijk zijn om te roken, juist omdát het schadelijk is. Het is een product met 'een bite' waarmee sommigen zich een onafhankelijk of stoer imago proberen aan te meten. De keerzijde van deze tolerante houding is wel dat een substantiële minderheid van de bevolking dóór blijft roken. In Nederland rookt nog $28 \%$ van de bevolking. Dit is hoog vergeleken met landen als 
Engeland, Finland, en Canada. Het roken is bij ons dan ook nog steeds een ernstig maatschappelijk probleem. Er overlijden jaarlijks meer dan 19.000 mensen door. Voor elke tabaksdode mag je er nog eens 20 bijtellen die chronisch ziek worden door het roken (Hyland et al., 2003). Dertien procent van onze totale ziektelast wordt erdoor veroorzaakt (Van der Lucht \& Polder, 2010). Het roken kost de staat, volgens een recente berekening, jaarlijks 2,4 miljard euro door ziektekosten, door verminderde productiviteit en door arbeidsongeschiktheid (PWC, 2010). Een schadepost van deze omvang kan geen enkele samenleving zich permitteren.

Deze schadepost gaat niet vanzelf weg. Het aantal rokers neemt de laatste jaren nauwelijks meer af. Daar is gerichte actie voor nodig en daar gaat deze openbare lezing over. Ik bespreek eerst de politieke context, omdat die context belangrijk is om te begrijpen waarom tabaksbeleid hier zo moeizaam tot stand komt. Daarna ga ik in op de meer traditionele aanpak van het roken. Deze aanpak richt zich op individuen. Ik zal laten zien dat deze aanpak tekort schiet om het maatschappelijk probleem van het roken aan te pakken. Ik presenteer daarna een andere benadering, die ik de populatie-aanpak noem. Ik laat een populatiemodel van tabaksontmoediging zien en ga aan de hand van dit model na welke strategieën mogelijk zijn om het roken in de samenleving verder te ontmoedigen. Met deze leerstoel wil ik vooral deze populatiegerichte benadering onder de aandacht brengen. Tot slot leg ik uit hoe ik in het onderwijs en het onderzoek wil proberen bij te dragen aan een beter begrip van de complexiteit van tabaksontmoediging.

\section{De politieke context van tabaksbeleid}

Ik wilde deze lezing niet ál te somber insteken, maar een 'reality check' is noodzakelijk. Laat ik beginnen met vaststellen dat veel Nederlandse rokers het feit dat ze roken, niet echt als een probleem zien. Slechts $22 \%$ van onze rokers denkt negatief over roken, terwijl dit bijvoorbeeld in Frankrijk 50\% is, in lerland 61\% en in Brazilië zelfs $81 \%$ (ITC Project, 2010). Uit vorig jaar vrijgekomen documenten van tabaksfabrikant Philip Morris weten we dat deze industrie al 20 jaar geleden onderzoek deed naar hoe er in landen over de hele wereld tegen het roken wordt aangekeken. Het is bijzonder spannend om deze documenten, die je tegenwoordig beter 'tobaccoleaks' zou kunnen noemen, te lezen en ik kan iedereen aanraden om er zelf eens in te grasduinen.' Uit een van de documenten die ik vond, bleek dat Nederlanders in vergelijking met andere landen opvallend tolerant zijn tegen roken en weinig zien in 
overheidsmaatregelen. ${ }^{2}$ Nederland verkeert in deze industrie-peilingen samen met landen als Duitsland, Oostenrijk en Denemarken steevast in dezelfde tabaksvriendelijke hoek.

Ik ben betrokken bij een internationaal vergelijkend wetenschappelijk onderzoek waarin alle Europese landen beoordeeld worden op de mate waarin ze maatregelen tegen het roken hebben doorgevoerd (Joossens \& Raw, 2007). Sinds 2004 organiseren we om de paar jaar een meting. In 2007 stond Nederland op plaats 14 (van de 30 landen), een gedeelde plaats met Hongarije en één plaats achter Bulgarije. Twee jaar eerder deden we het nog wat beter met een 1oe plaats. Feit is dus dat Nederland absoluut géén streng tabaksbeleid heeft, als we dit met andere landen in Europa vergelijken. Er zijn dus nog veel maatregelen mogelijk die in andere landen al wél zijn ingevoerd (Van der Wilk et al., 2007).

Momenteel lijkt de politiek hier echter niets in te zien. De nieuwe minister van Volksgezondheid, mevrouw Edith Schippers, heeft haar standpunt over roken helder verwoord in haar maiden speech, een week na haar aanstelling. ${ }^{3}$ Ik citeer: "Het is vanuit mijn ogen, vanuit mijn politieke overtuiging, absoluut een heilloze weg dat wij vanuit de overheid mensen in een keurslijf proberen te dwingen door verboden, geboden, beperkingen, spotjes met doemscenario's, betuttelende en betweterige teksten, (...) afbeeldingen van kapotte longen op sigarettenpakjes". Even later zegt ze: "Wij zijn politici. Wij zijn geen technocraten die zeggen: dit is een lijstje van zaken die het beste werken, dus dat doen wij automatisch. Dan kun je net zo goed een computer neerzetten." Daarmee is de toon van het huidige kabinet gezet. Het lijkt wel of er in Nederland als het om tabaksontmoediging gaat altijd een tegenwind waait. Met het nieuwe VVD-CDA kabinet lijkt deze tegenwind aangewakkerd te zijn tot een heuse storm, windkracht 10. Ik kan me levendig voorstellen dat lobbyisten voor Philip Morris, British-American Tobacco en al die andere fabrikanten die actief zijn in Nederland, de champagne hebben laten knallen toen bekend werd dat Edith Schippers minister van Volksgezondheid werd. $U$ zult merken dat mijn visie op tabaksontmoediging niet echt met deze wind mee waait, maar er juist tegenin gaat. Ik wil wél naar evidentie kijken, zonder een computer te willen zijn. Wetenschappelijke evidentie is belangrijk, maar het zou volstrekt naïef zijn om te denken dat dit doorslaggevend is voor politici. Dat bleek duidelijk uit het citaat van Edith Schippers. Gezondheid is slechts één van vele argumenten die een rol spelen (Mackenbach, 2009). Het probleem van het bestrijden van tabak is in de kern een politiek probleem.

Zie http://legacy.library.ucsf.edu/tid/fnq9ogoo/pdf

Zie https://zoek.officielebekendmakingen.nl/h-tk-20102011-15-13.html\#doe21 
Het is me meerdere keren opgevallen dat vertegenwoordigers van de tabaksindustrie zelfgenoegzaam en blakend van zelfvertrouwen op de publieke tribune zitten bij debatten in de Tweede Kamer over roken. De eerste keer dat mij dit opviel raakte ik er door in verwarring, want ik verkeerde in de veronderstelling dat zij een achterhoedegevecht voerden en nog slechts konden proberen te redden wat er voor hen nog te redden viel. Ik weet inmiddels beter. De industrie is steeds in controle geweest en zij heeft zowel het maatschappelijk debat over roken als de politieke besluitvorming diepgaand beïnvloed (Bouma, 2001). Deze beïnvloeding gaat nog onverminderd door. Er lijkt sprake van een bijzonder 'vruchtbare' wisselwerking tussen een actieve industrie (Nederland is een van de grootste tabaksproducenten) en de sociaalpolitieke traditie van polderen en consensus zoeken, waarbij veel ruimte is voor overleg met het bedrijfsleven en het zoeken naar oplossingen door zelfregulering in plaats van wetgeving (Andeweg \& Irwin, 2009). Historisch gezien is Nederland sterk gedomineerd door het liberale gedachtegoed met vrijheid en tolerantie als belangrijke waarden. In deze liberale omgeving is tabak moeilijk te bestrijden. De Nederlandse politiek lijkt door de industrie in slaap gesust en kijkt te weinig naar de keerzijde van de tolerantie van het roken, namelijk de enorme maatschappelijke schade die er het gevolg van is. Maar een echte analyse van de invloed van de industrie op de politiek moet eigenlijk nog gemaakt worden en ik roep politicologen en andere wetenschappers op om dit samen met mij in de toekomst te doen. 4

\section{Verschillende benaderingen van tabaksontmoediging}

Wereldwijd houden enorm veel mensen zich met tabaksontmoediging bezig. Dit jaar organiseert STIVORO samen met KWF Kankerbestrijding een Europees wetenschappelijk congres hierover. ${ }^{5}$ Het congres wordt in Amsterdam gehouden en zal druk worden bezocht door onderzoekers, deskundigen, maar ook door activisten. Mensen die zich bezighouden met tabaksontmoediging hebben meestal een sterke drijfveer om

4 Journalist Joop Bouma heeft een eerste beschrijving gemaakt van de vergaande bemoeienis van de industrie met het tabaksbeleid (Bouma, 2001), maar een wetenschappelijke analyse is nog niet uitgevoerd. Zolang dat niet gedaan is, blijft onduidelijk in welke mate de tabaksindustrie het beleid beïnvloedt. Ook zijn verschillende landenvergelijkende studies verschenen. In geen hiervan figureert Nederland (Marmor \& Liberman, 2004; Studlar, 2002). Over de Duitse situatie, die veel op Nederland lijkt, zijn al wel analyses gemaakt (Strunk et al., 2008; Grüning \& Gillmore, 2007). Hieruit blijkt dat de industrie in Duitsland nog veel invloed heeft op het tabaksbeleid.

5 De European Conference on Tobacco Control (ECToH) wordt van 28 - 30 maart in Amsterdam georganiseerd. 
dat werk te doen. Het is mij opgevallen dat die drijfveren in de praktijk uiteen kunnen lopen. Zo is er een groep die als belangrijkste drijfveer heeft het helpen van individuen. In deze groep wordt vooral nagedacht over steeds betere manieren om rokers te helpen bij het stoppen en worden ook lesprogramma's voor scholen ontwikkeld. In deze groep bevinden zich traditioneel veel medici en psychologen. Dan is er een andere groep die meer gedreven is door de wens om de schade van het roken voor de maatschappij als geheel te verminderen. Dit zijn bijvoorbeeld epidemiologen en mensen met een volksgezondheid achtergrond. Tussen beide groepen woedt soms een stevige discussie over prioriteiten, omdat investeren in interventies die voor een individu nodig zijn, niet altijd ook direct een populatiedoel dienen en andersom (Britton, 2009; Frohlich, 2008). Een van de grootste uitdagingen voor tabaksontmoediging is om beide benaderingen met elkaar te verbinden (Willemsen, 2010).

Ik bespreek nu eerst de aanpak van de mensen die zich vooral om het lot van individuen bekommeren. Ik noem dit de individugerichte benadering van tabaksontmoediging. Daarna presenteer ik de aanpak waarbij het meer gaat om het beschermen van de gezondheid van de hele populatie. Dit noem ik de populatiegerichte benadering. De benaderingen vullen elkaar aan.

\section{De individugerichte benadering}

De individugerichte aanpak van tabaksontmoediging is eigenlijk de traditionele aanpak van het roken. Jarenlang hebben wij er op vertrouwd dat het probleem van het roken volgens een planmatige, evidence-based manier op te lossen is, waarbij we uitgingen van een gedegen analyse van gedragsdeterminanten en daar vervolgens onze interventies op ontwikkelden. Het veld werd in de jaren '70 en een deel van de jaren '8o gedomineerd door psychologen die roken als een slechte gewoonte zagen. Het gedrag stond centraal en de aanpak was om mensen te motiveren niet te roken. Hard-core gezondheidsvoorlichting zou je dit kunnen noemen. Er waren twee strategieën: enerzijds jongeren motiveren en ondersteunen om er niet mee te beginnen en anderzijds rokers motiveren en ondersteunen om te stoppen.

Wat die jongeren betreft: elk jaar is er weer aanwas van nieuwe rokers. Dat zijn bijna allemaal adolescenten. Als die niet zouden beginnen met roken, lost het probleem zich in theorie vanzelf op. Er zijn in Nederland verschillende effectieve lesprogramma's voor scholen ontwikkeld (Crone et al., 2003; De Vries et al., 1994; Dijkstra, 1995). Het punt is alleen dat 
het effect van deze programma's beperkt blijft tot 1 of 2 jaar, waardoor het resultaat nauwelijks doorwerkt op populatieniveau (Hill, 1999; van Gelder et al., 2010). Meer in het algemeen kunnen we zeggen dat preventieve inspanningen gericht op jongeren via massamediale campagnes (Hopkins et al., 2001; Sowden \& Arblaster, 2003) of via lesprogramma's (Thomas \& Perera, 2006; Wiehe et al., 2005) nauwelijks effect hebben op het totale percentage rokers in de bevolking. ${ }^{6}$ Zelfs als er van de ene op de andere dag geen enkel kind meer zou beginnen met roken, wat natuurlijk volstrekt niet realistisch is, dan zou het nóg 40 jaar duren voordat het percentage rokers zou zijn gehalveerd (Levy

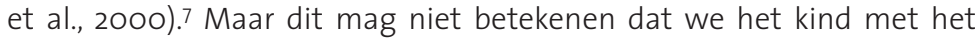
badwater weggooien. Uitstel van het beginnen met roken, al is het maar met 1 of 2 jaar, is een belangrijk doel op zichzelf, omdat mensen die op latere leeftijd beginnen met roken, minder roken, makkelijker met roken stoppen en minder kans hebben op ziekte (Taioli en Wynder 1991, Reid et al. 1992). Zonder rookpreventieprogramma's zou de industrie vrij spel krijgen om nieuwe aanwas te rekruteren (Myers, 1999).

Dan de volwassenen rokers: traditioneel worden rokers met gedragsmatige technieken geholpen bij het stoppen. Onderzoek vanuit de biowetenschappen maakte echter duidelijk dat sigaretten stoffen bevatten, met name nicotine, die inwerken op het centraal zenuwstelsel waardoor verslaving optreedt. Vanaf begin jaren '80, met de introductie van nicotinekauwgom, en later gevolgd door andere nicotinebevattende producten, medicaliseerde het veld. Eindelijk kon de dokter iets concreets bieden aan rokende patiënten. Hierdoor raakten artsen veel meer betrokken bij tabaksontmoediging. Tabaksgebruik werd een officiële verslavingsziekte, een chronische aandoening (APA, 1995; WHO 1992). Deze ziektegeoriënteerde benadering heeft effectieve farmacotherapie opgeleverd die de kern vormt van de moderne behandeling. Nederlandse rokers kunnen tegenwoordig beschikken over een behoorlijk arsenaal aan stopmethoden waarvan de effectiviteit is bewezen (Willemsen et al., 2003). De meest effectieve behandeling is een combinatie van farmacotherapie en gedragstherapie (CBO, 2004). Beide vormen van behandeling dragen ongeveer in gelijke mate bij aan het eindresultaat (Coleman, 2004). Het is goed om nog eens te benadrukken dat stoppen-

$6 \quad$ Een extreme positie wordt ingenomen door activisten die jongerenvoorlichting enkel als een valkuil of afleidingsmanoeuvre van de tabaksindustrie zien. Zie bijvoorbeeld Glantz (1996) en Levy et al. (2000). Goed nieuws is dat er aanwijzingen zijn dat wanneer het roken in de populatie van volwassenen afneemt, veel jongeren dit voorbeeld volgen (Chapman, 2007; Hill 1999). Dit komt waarschijnlijk doordat ouders door zelf te stoppen met roken een goed voorbeeld geven (Den Exter-Blokland et al., 2004; Otten, 2007), maar ook doordat op volwassenen gerichte voorlichtingscampagnes óók effect kunnen hebben op jongeren (White et al., 2003). 
met-rokentherapie een van de meest kosteneffectieve interventies is in het medisch arsenaal (Warner, 2006).

Wat is nu de beperking van deze benadering, gezien vanuit een populatieperspectief? Allereerst: met de meest effectieve combinatietherapieën worden lange-termijn succespercentages van ten hoogste $20-30 \%$ bereikt. We lijken er maar niet in te slagen om door dit plafond heen te breken. Maar wat belangrijker is: de beperking van deze aanpak is dat ze vooral gericht is op rokers die al willen stoppen en die daar actief hulp bij zoeken. Dat is een minderheid van de rokers, slechts enkele procenten. Met simulatiemodellen is aangetoond dat het vergroten van de effectiviteit van individuele stoppogingen alleen effect heeft op de totale populatie als heel veel rokers een stoppoging doen en er veel gebruik wordt gemaakt van stoptherapie (Levy et al., 2000; Levy et al., 2010; Zhu, 2006). ${ }^{8}$ De Inspectie van de Gezondheidszorg constateerde onlangs dat het bereik van individuele rookinterventies die via gemeenten aan de burgers worden aangeboden volstrekt onvoldoende is om nationale doelstellingen uit de Preventienota te realiseren (IGZ, 2010). Maar ook hier moeten we geen kinderen met badwater weggooien. Binnen een geïntegreerd model van tabaksontmoediging spelen effectief bewezen stoptherapieën toch een belangrijke rol. Rokers die uiteindelijk door populatiegerichte interventies zijn gemotiveerd om te stoppen moeten kunnen beschikken over effectieve, zo nodig intensieve vormen van ondersteuning (Warner, 2008). Een groeiend probleem met de populatiebenadering is dat deze zich richt op de massa en er relatief weinig aandacht is voor 'moeilijke' groepen, zoals oudere rokers, rokers met psychiatrische problematiek en rokers uit sociaal gedepriveerde bevolkingsgroepen. Rokers die niet kunnen stoppen kunnen zich gemarginaliseerd en gestigmatiseerd voelen. Hier raken we aan een ethisch aspect. Een overheid die regelgeving en campagnes invoert heeft tevens een morele plicht om rokers zo goed mogelijk op te vangen en te ondersteunen. 9

8 De populatie-impact van een interventie is een functie van drie factoren: 1. de inherente werkzaamheid van de interventie (efficacy), 2. de kwaliteit van de praktijkuitvoering en 3. het gebruik (Thyrian \& John, 2007). De werkzaamheid is allesbepalend voor individuen, maar de omvang van het gebruik is allesbepalend voor populaties.

9 Het bieden van stoppen-met-roken hulp kan een ondersteunende en legitimerende functie hebben en vergroot het maatschappelijk draagvlak voor regelgeving (Burns, 2000; Britton, 2009). Warner (2008) formuleerde dit zo: "It will soften the blow". 


\section{De populatiegerichte benadering}

Met het inzicht dat louter een aanbod van individugerichte interventies tekortschiet om het roken in de samenleving te verminderen, is in veel landen de focus verschoven naar zogenaamde upstream interventies $(\mathrm{NCl}, 2007) .{ }^{10}$ Deze verschuiving ging samen met de ontwikkeling van geïntegreerde, zogenaamde ecologische modellen van gezondheidsbevordering. ${ }^{11}$ Men begrijpt steeds beter dat roken in populaties het best kan worden bestreden met programma's rechtstreeks gericht op de hele populatie, maar wel met een daarbinnen passend aanbod van individugerichte interventies ( $\mathrm{NCl}, 2007)$. Internationaal is er overeenstemming over welke populatie-interventies werken. Dit zijn hoge accijns op tabak, rookverboden in openbare gebouwen en werkplekken, reclame- en sponsorverboden, massamediale anti-roken campagnes, en gezondheidswaarschuwingen op sigarettenpakjes (WHO 2003; Worldbank, 1999).12 Elk van deze maatregelen is in Nederland ingevoerd, maar nooit in de meest optimale vorm. Tabaksaccijns is in Nederland nog relatief laag (Joossens \& Raw, 2007). Er is wel een rookverbod voor de werkplek, maar juist de horeca waar mensen die uitgaan zeer intensief worden blootgesteld aan tabaksrook, is nog niet volledig rookvrij. Sterker nog: door het gedogen van het roken in kleine cafés wordt op grote schaal weer in de horeca gerookt. Er is wel een rookverbod in het openbaar vervoer, maar op alle perrons van de treinstations zijn gedoogzones gecreëerd rondom rookpalen. $\mathrm{Er}$ is wel een algemeen reclameverbod, maar geen verbod op het uitstallen van sigaretten in winkels. Er zijn af en toe massamediale campagnes gericht op jongeren en soms ook op volwassenen, maar er is geen structureel budget zodat er ook met enige regelmaat campagnes worden gevoerd. ${ }^{13}$ Er zijn wel tekstwaarschuwingen op sigarettenpakjes, maar geen foto's.

Ik wil nu wat dieper ingaan op de populatiebenadering van tabaksontmoediging. Hoe werkt die? Het belangrijkste kenmerk is dat een effectieve populatiebenadering veel minder gericht is op rokers zelf, maar veel meer op hun omgeving. Dat kan de fysieke omgeving zijn, maar ook de sociale omgeving.

10 Er is nog een tussenniveau, namelijk het niveau van communities, zoals buurten of bedrijven, waarmee soms goede resultaten zijn behaald. Belangrijke voorbeelden zijn COMMIT en ASSIST in de VS ( $N C l, 2007)$, North Karelia Project in Finland, en Hartslag Limburg, wat dichter bij huis. Een ernstige beperking van deze benadering is de enorme energie en moeite die het kost om dit goed te organiseren.

"Het vakgebied waarbinnen mijn leerstoel valt, de gezondheidsbevordering (health promotion), is een combinatie van voorlichting en omgevingsverandering (Kok et al., 2000).

12 Het voert te ver om in het bestek van deze lezing de effectiviteit van maatregelen te bespreken. Daarvoor verwijs ik naar eerdere reviews (Willemsen, de Zwart, \& Mooy, 1998; Willemsen \& de Zwart, 1999; Willemsen, 2005).

13 Een hoge frequentie is beslist noodzakelijk voor populatie-effecten (Bala et al., 2008: Brin et al., 2010; Wakefield, 2010). 


\section{De fysieke en sociale omgeving}

De rol van de fysieke omgeving als gedragsdeterminant is lange tijd onderbelicht gebleven (Brug \& van Lenthe, 2006). Een van de belangrijkste recente inzichten vanuit de psychologie is dat menselijk gedrag veel sterker door automatische en onbewuste processen wordt gestuurd dan vroeger werd gedacht en dat het bewuste 'slechts' een ondersteunende functie heeft (Baumeister \& Masicampo, 2010). Zelfregulerende cognities (bijvoorbeeld een voornemen om niet te roken) gaan in het hier en nu continu een strijd aan met krachtige automatische processen, zoals impulsen en driften die door de omgeving worden opgewekt en die onmiddellijk bevredigd willen worden (West, 2007). De fysieke omgeving beïnvloedt het gedrag rechtstreeks zonder tussenkomst van cognities. Controle over de fysieke omgeving is dus belangrijk als we gedrag willen beïnvloeden (Tiemeijer et al., 2009). De tabaksindustrie heeft dit al heel lang door. Philip Morris verklaarde in een interne notitie in 1991: "We are after intrusive visibility" ("we zijn uit op opdringerige zichtbaarheid") (Pollay, 2007). Zo promoot de industrie haar producten via talloze verkooppunten in supermarkten, tankstations en gemakswinkels, voert ze sluikreclame voor sigaretten in films, promoot ze in toenemende mate tabak via social media als Hyves, Facebook en Twitter, en verleiden de in Nederland nog steeds toegestane sigarettenautomaten rokers tot impulsaankopen. Het feit dat al deze, ik noem het maar rookgerelateerde omgevingsprikkels, nog steeds aanwezig zijn, toont aan dat zelfregulering door de industrie niet werkt. De industrie heeft immers baat bij zoveel mogelijk opdringerige zichtbaarheid. Regelgeving is echt noodzakelijk om dit te verminderen. Nu wil ik ingaan op de sociale omgeving. Laat ik eerst de industrie weer aan het woord laten. In een intern rapport van Philip Morris uit 1999 vond ik de opmerking dat een rookverbod in de horeca hen op twee manieren schade toebrengt. Ten eerste door een direct effect op de tabaksconsumptie, maar:

"a more important effect is that on the social acceptability of smoking. Attempts to depict tobacco use as anti-social get a powerful boost when its use is banned in social settings. This impact on our business, whilst slower, is just as real."

De tabaksindustrie lijkt dus vooral te vrezen voor een afname van de sociale acceptatie van het roken, omdat dit op termijn gevolgen zal hebben voor hun omzet. De sociale acceptatie, ofwel de sociale norm, is dus belangrijk. De sociologie leert ons dat gedrag van individuen in belangrijke mate wordt gestuurd door gedeelde sociale normen. 
Normatieve factoren kunnen verklaren waarom populaties van elkaar verschillen en hoe populaties in de tijd veranderen (Chaiton et al., 2008). De Britse sociaal-epidemioloog Geoffrey Rose (1992) zei het zo:

"Social norms rigidly constrain how we live (...). We may think that our personal life-style represents our own free choice, but that belief is often mistaken. It is hard to be a non-smoker in a smoking milieu, or vice versa. (...) The population strategy of prevention (....) faces the formidable difficulty of needing to change the majority, which means redefining what it is to be regarded as normal" (Rose, 1992).

In Nederland is die taak inderdaad 'formidable'. Ik ga er vanuit - en ik denk dat dit een van de weinige visies is die ik met de tabaksindustrie deel - dat de sociale norm over roken dé centrale factor is waar tabaksontmoediging in populaties op de lange termijn om draait.14 De laatste jaren komen er ook uit onafhankelijk onderzoek steeds meer aanwijzingen dat de sociale norm inderdaad een belangrijke factor is bij het stoppen met roken in populaties en de geleidelijke overgang naar een rookvrije samenleving (Alamar \& Glantz, 2006; Brown et al., 2009; Hammond et al., 2006; Hosking et al., 2009). Ik vermoed dat stoppen met roken vaak vooraf wordt gegaan door veranderingen van de maatschappelijk norm en dat die normen vervolgens 'doordruppelen' naar de kleinere sociale verbanden waar de feitelijke beïnvloeding plaatsvindt. Sociale netwerkanalyse heeft inderdaad laten zien dat stoppen met roken zich niet willekeurig voltrekt binnen een populatie, maar dat dit langs familie- en vriendenverbanden verloopt (Christakis \& Fowler, 2008). De sterkste beïnvloeding vindt plaats binnen groepjes van met mensen die sterk met elkaar verbonden zijn. Zo ontstaan er sociale groepen met heel weinig rokers en ander groepen waar nog relatief veel wordt gerookt. De sociale norm heeft dan ook een prominente plaats gekregen in mijn populatiemodel van tabaksontmoediging (zie Figuur 1).

14 Het inzicht dat de oplossing voor het tabaksprobleem - als die al bestaat - ligt bij fundamentele veranderingen in sociale normen, is ook door anderen onderkend. Zie bijv. Warner (2006). 


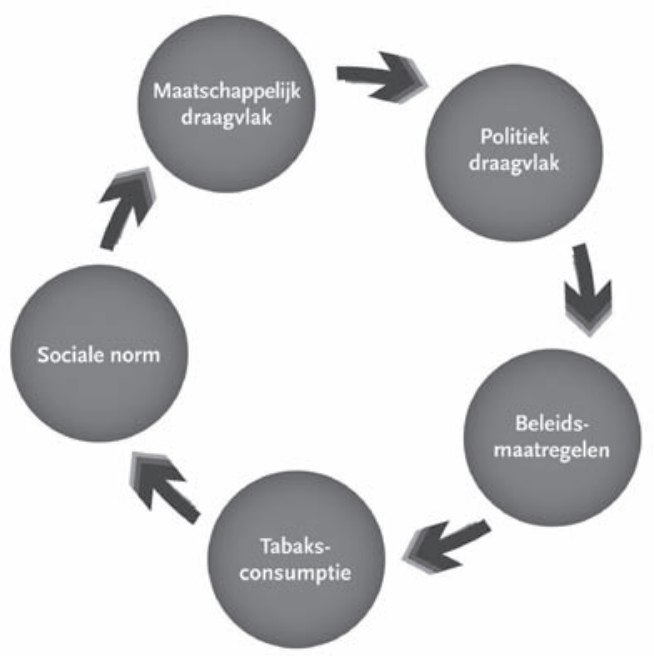

Figuur 1: Het populatiemodel van tabaksontmoediging

U kunt dit model beschouwen als het vliegwiel van tabaksontmoediging. Een vliegwiel is een groot wiel dat al draaiende energie verzamelt. Belangrijk bij een vliegwiel is het zogenaamde traagheidsmoment. Een vliegwiel is relatief zwaar en het is vanwege het traagheidsmoment moeilijk op gang te krijgen, maar als het eenmaal draait laat het zich moeilijk afremmen. Precies zo stel ik mij tabaksontmoediging in een populatie ook voor. Als er voldoende momentum is draait het wiel langzaam door. De tabaksconsumptie neemt af, de groep rokers wordt kleiner, de sociale norm wordt minder tolerant tegen roken, er ontstaat meer draagvlak binnen de samenleving voor maatregelen om het roken verder te ontmoedigen, de politieke wil om dit te doen neemt toe en de kans dat die maatregelen er komen wordt groter. Maatregelen zullen weer bijdragen aan verdere afname van de tabaksconsumptie, en zo verder. Maar als de vaart eruit is, gebeurt er ook helemaal niets meer. 


\section{Het vliegwiel in beweging brengen}

Het praktische probleem spitst zich nu toe op de vraag: hoe dit vliegwiel, dat in Nederland een aantal jaren geleden knarsend tot stilstand is gekomen, weer in beweging te krijgen? Het wiel bestaat uit vijf bolletjes. In theorie kan een zetje worden gegeven aan elk 'bolletje'. Laten we ze één-voor-één langslopen.

Allereerst kunnen we proberen om het onderste bolletje, de tabaksconsumptie, een zet te geven. Dat kan op twee manieren. De eerste manier is via grootschalige acties waarin rokers worden opgeroepen om op een bepaald moment, bijvoorbeeld op 1 januari of een ander symbolisch moment, te stoppen met roken. Als er voldoende budget is om de actie flink via TV en andere kanalen bekend te maken, kan dit honderdduizenden succesvolle stoppers opleveren. Het percentage rokers in de populatie kan per actie ongeveer 1 procentpunt worden verlaagd (van den Putte et al., 2005; Mudde \& De Vries, 1997; Westerik \& van der Rijt, 2001). Dit is een indrukwekkend resultaat. Het is dan ook teleurstellend dat dit type actie in Nederland nog maar drie keer is toegepast. Vaker ging niet vanwege onvoldoende budget. Stopacties zijn dus effectief om tabaksconsumptie te verminderen, maar als ze niet regelmatig worden herhaald verdwijnen de effecten weer (Wakefield et al., 2010). De andere beproefde manier om direct de omvang van de consumptie te beïnvloeden is via accijnsverhoging. De tabaksconsumptie neemt met ongeveer $4 \%$ af bij elke $10 \%$ verhoging van de sigaretten prijs (Gallet \& List, 2003). Het effect op jongeren en rokers uit lagere sociaaleconomische groepen is zelfs groter. Er is in Nederland nog veel ruimte om de prijs van tabak te verhogen, omdat ons prijsniveau zich ergens in de middenmoot van Europa bevindt. Als dit gecombineerd wordt met een doelheffing, zodanig dat een deel van de baten gestort wordt in een fonds van waaruit de voorlichting over roken structureel kan worden gefinancierd, snijdt het mes zelfs aan twee kanten. Steeds meer landen in Europa gaan over tot het oormerken van een deel van de tabaksopbrengsten voor de voorlichting over roken (WHO, 2007). Uit cijfers uit het Continu Onderzoek Rookgewoonten van STIVORO bleek dat bijna 2/3 van de Nederlandse bevolking hier vóór is. Ons Ministerie van Financiën heeft dit echter lang geleden taboe verklaard. Dit taboe zal moeten worden verbroken, maar dit zal een proces van zeer lange adem zijn. Ondertussen verdient de overheid flink aan de tabaksverslaving van de bevolking, 1,8 miljard euro per jaar (van der Wilk et al., 2007), zonder ook maar iets van dat geld rechtstreeks te benutten om het leed dat door die verslaving wordt veroorzaakt, te verminderen of te verzachten. Dit is een perverse situatie die op den duur onhoudbaar is. 
De volgende mogelijkheid om het vliegwiel weer te laten draaien is door het tweede bolletje een zet te geven. Dat is de sociale norm. Die moet minder pro-roken worden. Ik heb eerder laten zien dat de norm in Nederland nog opvallend pro-roken is. Er wordt daarom wel gezegd dat roken moet 'de-normaliseren' (Lavack, 1999; STIVORO, 2010). Er zijn twee manieren: via rookverboden en door massamediale campagnes.

De eerste manier om de sociale norm te beïnvloeden is dus via rookverboden, althans als we mogen afgaan op wat de tabaksindustrie hier over zegt: "Bans and excessive restrictions limit the places and time consumers can enjoy our products. This will have an unquantifiable impact on social acceptability". ${ }^{15}$ Maar niet alleen de industrie zegt dit. Hoewel er nog niet veel onderzoek naar is gedaan, zijn er toch wel wat studies die hebben laten zien dat het invoeren van rookverboden in openbare ruimten en op werkplekken leiden tot een versterking van de norm dat je niet behoort te roken in de aanwezigheid van niet-rokers. ${ }^{16}$ De andere manier om normen te veranderen is via massamediale campagnes. Hiervoor is wel een lange periode nodig waarin regelmatig en frequent campagne wordt gevoerd. In zo'n campagne kan dan voor verschillende voorlichtingsboodschappen worden gekozen, zoals 'passief roken is schadelijk', 'nicotine is verslavend' of 'de tabaksindustrie manipuleert'. ${ }^{17}$ Met name campagnes die de link tussen roken en gezondheid leggen, hebben in Nederland nog een belangrijke rol te spelen. Vaak wordt gezegd dat iedereen allang weet dat roken slecht is. De meeste rokers beseffen inderdaad wel dat roken niet goed voor ze is en ze weten ook allemaal wel dat je er longkanker van kunt krijgen. Maar daar houdt de kennis bij de meesten wel zo'n beetje op. Rokers weten nog weinig over de specifieke risico's, laat staan dat men risico's juist waardeert en interpreteert (Chapman \& Liberman, 2005). Het is een mythe dat Nederlandse rokers over voldoende kennis beschikken over de schade die tabak kan aanrichten. Tabaksrook brengt een verbijsterend aantal schadelijke stoffen diep in het menselijk lichaam en kan op heel veel plaatsen schade veroorzaken (USDHHS, 2010). Recentelijk bleek uit eigen onderzoek hoe beperkt de kennis van de gemiddelde Nederlandse roker is. Dit zijn ronduit schokkende cijfers. Van de 19 landen waar wij gegevens van hadden, waren de Nederlandse rokers bijvoorbeeld het

\footnotetext{
Zie: http://legacy.library.ucsf.edu/tid/zli81goo/pdf

Zie voor een overzicht Brown et al (2009)

Campagnes rondom deze drie thema's hebben een doorslaggevend rol gespeeld in de 'tobacco war' die in Californie is uitgevochten in de jaren '9o (Glantz \& Balbach, 2000).
} 
minst op de hoogte van het feit dat meeroken schadelijk is (zie Figuur 2). ${ }^{18}$ In de Verenigde Staten zegt $80 \%$ van de rokers dat tabaksrook schade toebrengt aan anderen. In lerland zegt 91\% van de rokers dit en in Frankrijk zelfs 96\%. Maar in Nederland is nog maar 61\% van de rokers hiervan overtuigd. Uit hetzelfde onderzoek bleek dat Nederlandse rokers ook nog een kennisachterstand hebben wat betreft de relatie tussen meeroken en longkanker en het effect van roken op hart- en vaatziekten.

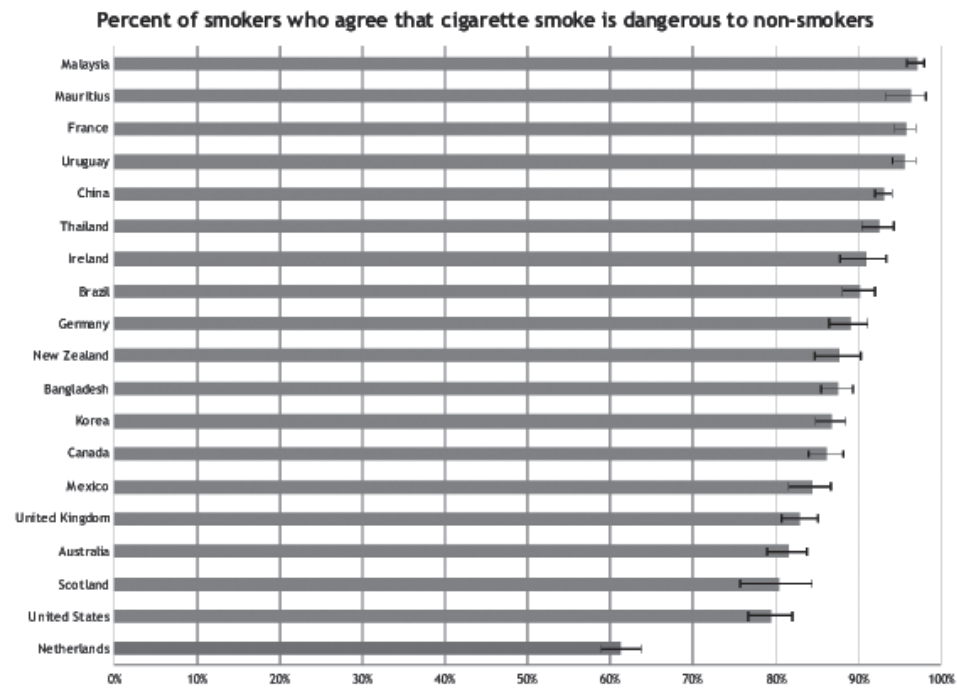

Figuur 2: Percentage rokers dat meeroken schadelijk vindt in 19 landen

18 Ongepubliceerde data uit het International Tobacco Control Evaluation Research (ITC) project, mij ter beschikking gesteld voor deze oratie.

19 Ik ken er maar twee vanuit STIVORO, gericht op volwassenen. In 1987 voerde STIVORO een campagne over de schade door passief roken 'Wie helpt de niet-roker van het roken af?. Deze campagne was dusdanig bedreigend voor de industrie dat 14 Nederlandse tabaksfabrikanten gezamenlijk eerst naar de reclamecodecommissie en toen naar de rechter stapten om de campagne te verbieden. Hoewel de zaak door STIVORO feitelijk gewonnen werd doordat het kon aantonen dat de campagne-uitingen in overeenstemming waren met de wetenschappelijke evidentie over risico's van meeroken, werd STIVORO onder politieke druk gedwongen om een schikking te accepteren (Bouma, 2001). De industrie buitte dit vervolgens slim uit door in de media te verklaren dat "volstrekt niet is aangetoond dat passief roken schadelijk zou zijn voor de gezondheid". De andere campagne dat aanschouwelijk probeer te maken wat het roken met iemand doet, is in de negentiger jaren door STIVORO in bioscopen vertoond. Het was een in Canada geproduceerd filmpje ('Joanne') waarbij jonge meisjes een spiegel werd voorgehouden van wat tabak met je uiterlijk doet. De campagne is helaas niet echt geëvalueerd, maar kwalitatieve gegevens hebben uitgewezen dat de campagne veel indruk maakte op rokers en nog steeds herinnerd wordt. 
Deze kennisachterstand is niet geheel onbegrijpelijk als we kijken naar het aantal campagnes in Nederland die echt gingen over roken en gezondheid. Die moet je echt met een vergrootglas zoeken. ${ }^{19}$ Voor campagnes over de gezondheidsrisico's is altijd weinig animo geweest bij de overheid. Zo heeft de overheid ervoor gekozen om bij het invoeren van de rookvrije horeca in 2008 in de begeleidende informatiecampagne niet in te gaan op waarom het eigenlijk zo belangrijk is voor de volksgezondheid om cafés en restaurants rookvrij te maken. Dit staat in contrast met landen waar de horeca zonder noemenswaardige problemen rookvrij werd gemaakt en waar steeds een langdurige campagne aan vooraf ging om dit uit te leggen. In Nederland lijkt er een taboe te zijn op campagnes die de feiten tonen over wat roken met het lichaam doet. Het is beslist nodig dat ook dit taboe wordt doorbroken.

Deze campagnes mogen wat mij betreft ook best hard en confronterend zijn. Stevige campagnes, mits effectief natuurlijk, lijken mij gezien de grote maatschappelijke schade door het roken alleszins verantwoord. ${ }^{20}$ Vaak wordt gedacht dat massamediale campagnes om gedrag te beïnvloeden niet werken. Voor roken geldt echter dat er inmiddels veel méér onderzoek gedaan is naar de effectiviteit van anti-roken campagnes dan naar campagnes gericht op enig ander risicogedrag (Wakefield, et al., 2010). De bewijsvoering voor een positief effect van tabakscampagnes op gedrag is relatief sterk.

Campagnes hebben eigenlijk een dubbele functie. Enerzijds zijn ze op het individu gericht en beïnvloeden ze kennis, attitude en motivatie van rokers om te willen stoppen. Anderzijds - en dat is volgens mij minstens zo belangrijk - kunnen ze maatschappelijke normen beïnvloeden (Wakefield et al., 2010). Hierdoor kan er meer draagvlak voor verdere overheidsmaatregelen ontstaan. Deze belangrijke functie van anti-roken campagnes is in Nederland onderbelicht. Campagnes worden hier vooral 'afgerekend' op of ze op de korte termijn tot gedragsverandering leiden en men is hier altijd erg bezorgd over mogelijke averechtse effecten op kleine subgroepen van individuen binnen de populatie, zoals rokers die niet open staan voor de boodschap. Het lange termijn effect op sociale

20 Extreem schokkende varianten lijken niet goed te passen bij de Nederlandse cultuur. Maar wat denk ik wel kan zijn campagnes waarbij op een realistische en eerlijke manier zichtbaar wordt gemaakt wat het roken met het lichaam doet of wat de emotionele gevolgen ervan kunnen zijn. Er is veel onderzoek gedaan waaruit blijkt dat het appelleren aan emoties de effectiviteit van campagnes vergroot (Biener et al., 2006; Timmers \& van der Wijst, 2007; de Pelsmacker, 2010). Belangrijk is wel dat de roker tevens informatie krijgt over effectieve steun, zodat hij of zij ook daadwerkelijk kan stoppen. Vaak wordt als voorbeeld de Australische ' Every cigarette is doing you damage' campagne aangehaald. Elke keer dat die campagne in Australië werd uitgezonden resulteerde dit in een toename van negatieve gedachten over het roken, meer rokers die willen en ook gingen stoppen met roken en een toenemend gebruik van de stoppen-met-roken hulptelefoon (Borland \& Balmford, 2003). 
normen en maatschappelijk draagvlak voor maatregelen zijn echter veel belangrijker. Vooral kennis over de schade door meeroken. Ook hierbij heb ik weer een mooie quote van de industrie. Ditmaal van onderzoekers in opdracht van Phillip Morris. Zij concluderen na een analyse van data uit een groot aantal landen: The desire for further restrictions is being driven by people's concerns about the health risk of ETS. ${ }^{21}$ There is a very clear correlation between the two items and this is much stronger than any other driving factor. ${ }^{22}$ Hoe meer bezorgdheid in een land over het meeroken, hoe groter het draagvlak voor maatregelen om er iets tegen te doen. Heel logisch eigenlijk. ${ }^{23}$ Campagnes zijn dus echt noodzakelijk om onze kennisachterstand in te lopen.

De derde manier waarop het vliegwiel in beweging kan worden gebracht, is door het bolletje waarin staat 'maatschappelijk draagvlak voor maatregelen' een zetje te geven. Hier komen we op het domein van wat in het Engels zo mooi media advocacy wordt genoemd of ook wel agenda setting (Walgrave \& van Aelst, 2006). Media advocacy is het gebruiken of beter gezegd bespelen van de media om jouw onderwerp op de politieke en maatschappelijke agenda te krijgen (Chapman \& Lupton, 1994; Wallack \& Dorfman, 1996). Dit is een bijzonder effectieve strategie bij tabaksontmoediging gebleken (Niederppe et al., 2007; $\mathrm{NCl}$, 2008). Om de politieke agenda te bepalen moet een bericht op de juiste manier worden geformuleerd. Ook hier hebben de Engelsen weer een mooi woord voor dat moeilijk in het Nederlands is te vertalen: framing noemen ze dat. De manier waarop het debat wordt 'geframed' bepaalt in belangrijke mate hoe er over gedacht en gesproken wordt (Benford \& Snow, 2000). De tabaksindustrie is hier erg bekwaam in (Fox, 2005). Ik wil daar een voorbeeld van geven. ${ }^{24}$

De industrie stelt ontmoediging van het roken als een economische kwestie voor. 'Tabaksfabrikanten dragen bij aan onze economische voorspoed', is de boodschap. De oppositie tegen het rookverbod op de werkplek en later ook in de horeca werd inderdaad vooral opgehangen

21 ETS is Environmental Tobacco Smoke, ofwel omgevingstabaksrook.

22 Zie http://legacy.library.ucsf.edu/tid/fnq9ogoo/pdf

23 Uit een onderzoek dat ik enkele jaren geleden zelf deed bleek ook dat het draagvlak voor verdergaand tabaksbeleid vooral afhangt van de kennis over de schade door meeroken (Willemsen, 2006).

24 Een andere voorbeeld is het framen van het rookprobleem is in termen van tolerantie en wederzijds respect. Ik heb met een student een analyse uitgevoerd van interne documenten van de tabaksindustrie (van de Bos, 2010). Hieruit bleek hoe zij via campagnes met slogans als 'Roken? We lossen het samen wel op' en 'Genieten moet mogen', de Nederlandse bevolking in de jaren ' 90 probeerde aan het verstand te brengen hoe het probleem van het meeroken het beste kan worden opgelost: namelijk niet door verboden maar door tolerantie. In de documenten vonden we resultaten van onderzoek dat de industrie had laten uitvoeren. Hieruit bleek dat de sociale acceptatie van het roken na de campagnes was toegenomen. 
aan economische bezwaren. Wij hebben een systematische analyse uitgevoerd op artikelen die verschenen in enkele grote dagbladen in de periode rondom de invoering van de rookvrije horeca. Uit deze mediaanalyse bleek dat het aantal krantenartikelen dat het rookverbod in verband bracht met gezondheid veel geringer was dan het aantal artikelen over mogelijke financiële problemen voor de horeca (Nagelhout et al., submitted). De tegenstanders van de rookvrije horeca hebben maandenlang de kranten weten te domineren met het verhaal van de kleine kroegen die in verzet kwamen tegen een betuttelende overheid. ${ }^{25}$

Dit voorbeeld illustreert dat de industrie met succes de methode van media advocacy toepast. De strijd om het roken in de samenleving wordt vooral via de media gevoerd en de gezondheidsorganisaties doen er goed aan zich vooral in het bespelen van de media te bekwamen. ${ }^{26}$

Dan komen we bij het vierde bolletje, het politiek draagvlak voor maatregelen. Om dit een zetje te geven kan er aan lobby en pleitbezorging worden gedaan. Dat gebeurt doorgaans achter de schermen. Ervaring met lobby in Amerika (Glantz \& Balbach, 2000) en in andere landen (WHO, 2008) heeft duidelijk gemaakt dat een lobbytweekamp uiteindelijk altijd door de tabaksindustrie wordt gewonnen. Zij hebben simpelweg veel meer middelen en meer, laten we zeggen, 'strategische connecties'. Dit is onlangs weer gebleken uit journalistiek speurwerk van NRC Next dat aan het licht bracht dat Hans Hillen, lid van het huidige regeringskabinet, tot voor kort nog betaald adviseur was van British American Tobacco. ${ }^{27}$ De industrie kan daarom het effectiefst worden bestreden door de rol die de tabaksindustrie achter de schermen speelt, via de media, in de openbaarheid te krijgen (Glantz \& Balbach, 2000). De Nederlandse overheid heeft zich in 2005 verbonden aan een internationaal verdrag over tabaksontmoediging van de WHO. Een van de belangrijkste bepalingen van dit verdrag is dat de overheid over de totstandkoming van tabaksbeleid niet dient te communiceren met de tabaksindustrie (WHO 2003, 2008). En als contacten toch echt noodzakelijk zijn, dan moeten die openbaar worden gemaakt. In het Nederlandse poldermodel is het echter gebruikelijk om juist met alle maatschappelijke partijen te praten en dus ook met de tabaksindustrie.

25 Journalistiek speurwerk suggereerde dat de tabakslobby tot dit verzet had aangezet (Baltesen \& Rosenberg, 2009).

26 In de kern gaat het om de vraag welke partij het succesvolst is in het bezetten van de 'moral high ground'. Zie Fox (2005) die een voorstel doet voor een ethische context van tabaksontmoediging en Advocacy Institute (2007) voor een 'how-to'.

27 Zie http://vorige.nrc.nl/binnenland/article2643635.ece/Hillen_verzweeg_advieswerk. 
Op het uitsluiten van de industrie lijkt nog een taboe te rusten. ${ }^{28}$ Ook dit laatste taboe zou moeten worden verbroken wil Nederland een werkelijk effectief en onafhankelijk tabaksontmoedigingsbeleid kunnen ontwikkelen.

En dan is er tot slot nog het laatste balletje. Die staat voor het invoeren van nieuwe maatregelen en nationale wetgeving. Dit bolletje kan vooral een zet krijgen via Europese wetgeving. Het tabaksbeleid wordt tegenwoordig grotendeels in Brussel bepaald. De Europese Commissie voert een actief tabaksbeleid en wetgeving is bindend voor de lidstaten.Zo zijn de huidige tekstwaarschuwingen op onze sigarettenpakjes gekomen door een Europese bepaling uit 2001. Ook het huidige reclameverbod vloeit rechtstreeks voort uit Europese regelgeving. Momenteel is een nieuwe Europese richtlijn in voorbereiding, waarin bepalingen komen die bindend zijn voor Nederland. Zo verwacht ik dat Nederland over enkele jaren van Brussel afschrikwekkende foto's op sigarettenpakjes moet plaatsen, sigarettenautomaten moet verbieden en dat sigaretten niet meer zichtbaar mogen worden uitgestald in winkels. Ook zit in de pijplijn dat bepaalde geur- en smaakstoffen die sigaretten extra aantrekkelijk maken voor jongeren, verboden gaan worden. Ik spreek hierbij mijn hoop uit dat de Nederlandse overheid weerstand weet te bieden aan de lobby van de industrie en de totstandkoming van deze Europese regelgeving niet gaat saboteren.

Eigenlijk moet de context waarin beleidsmaatregelen tot stand komen nóg breder worden gezien dan alleen Europa. Feitelijk wordt de strijd om tabak steeds meer over onze hoofden heen gevoerd. Het is een strijd tussen twee giganten. De Wereldgezondheidsorganisatie en de internationale tabaksproducenten voeren een werkelijke titanenstrijd waarbij de inzet de jaarlijkse sterfte van miljoenen mensen is tegen een miljardenomzet (McKinlay \& Marceau, 2000). De WHO heeft als belangrijkste wapen het zogenaamde FCTC verdrag ingezet. Dit staat voor Framework Convention on Tobacco Control. Dit is een internationaal kaderverdrag voor tabaksontmoediging dat door de meeste landen in de wereld is geratificeerd. Nederland deed dit in 2005. Hierdoor heeft Nederland zich verplicht om een heel pakket van maatregelen tegen het roken in te voeren. ${ }^{29}$ Sommige daarvan zijn wel gerealiseerd, andere nog niet of onvolledig. Het is belangrijk dat de overheid dit internationale verdrag naleeft en dan niet alleen naar de minimale letter van de wet

28 De tabaksindustrie vecht juist deze specifieke bepaling 5.3 aan en probeert het te ondergraven, onder meer door actief het nieuwe 'better regulation' beleid van de EU te ondersteunen (Smith et al., 2009). 
zoals nu gebeurt, maar in de geest ervan. Gezondheidsorganisaties en andere maatschappelijke partijen kunnen in Nederland nog een véél grotere rol spelen in tabaksontmoediging dan nu gebeurt. Een van de belangrijkste dingen die zij kunnen doen is de overheid controleren en stimuleren zodat die zich méér in gaat spannen om een tabaksbeleid te voeren dat werkelijk op de lijn ligt zoals de WHO het bedoelt. ${ }^{30}$

\section{Taboes rond tabaksbeleid}

Ik hoop duidelijk gemaakt te hebben dat er veel mogelijkheden zijn om het vliegwiel van tabaksontmoediging weer aan het draaien te krijgen en dat maatschappelijke organisaties hier een belangrijke rol bij kunnen spelen. Ik heb betoogd dat er naast de individugerichte voorlichtingsaanpak een populatiegerichte aanpak nodig is waarbij maatschappelijke actie nodig is. Er is meer systeemdenken nodig, waarbij ook de rol van de tabaksfabrikanten en de politiek in de analyse worden betrokken (Borland et al., 2010; NCl, 2007). Mijn vliegwielmodel biedt veel concrete aangrijpingspunten om de huidige impasse te doorbreken. Maar ik heb ook laten zien dat dit niet makkelijk zal zijn binnen de Nederlandse context. Er zijn immers echte taboes die eerst doorbroken moeten worden. Ik heb er drie genoemd. Ten eerste het doorbreken van het taboe op accijnsverhoging met geoormerkt geld voor tabaksbeleid. Ten tweede het taboe op meer confronterende campagnes over de gevolgen van roken en meeroken voor onze gezondheid. Die campagnes zijn écht nodig om de enorme kennisachterstand in Nederland in te lopen. En ten derde het taboe op het doorsnijden van de banden die de overheid heeft met de tabaksindustrie. Sommige taboes zijn er om doorbroken te worden. Dit geldt zeker voor de taboes rondom het Nederlandse tabaksbeleid. De eerste stap is om ze onder ogen te zien en bespreekbaar te maken.

\section{Onderzoek en onderwijs}

Maar wat ga ik nu zelf doen in het kader van deze leerstoel? Ik bespreek eerst het onderwijs en daarna het onderzoek.

\footnotetext{
29 Dit is allemaal vastgelegd in precieze richtlijnen waarover in internationale conferenties onderhandeld wordt. De tabaksindustrie steekt energie in pogingen om dit proces te beïnvloeden (Smith et al., 2010; Neuman et al., 2002).

30 Dit kan bijvoorbeeld door als organisatie lid te worden van de Framework Convention Alliance (FCA), een internationaal netwerk van maatschappelijke organisaties die de implementatie van de FCTC bepalingen ondersteunen.
} 


\section{Onderwijs}

Wat het onderwijs betreft wil ik een bijdrage leveren aan verschillende onderwijsmodulen binnen de Faculteit. Het zou prachtig zijn als het onderwerp tabak op meer plaatsen binnen het curriculum zou terugkomen, zodat studenten uiteindelijk de complexiteit van tabaksontmoediging gaan zien en de vele mogelijke oplossingen in een breder verband kunnen plaatsen. Ik ben alvast erg blij met het college over totstandkoming van Europees tabaksbeleid dat ik mag geven binnen het bachelorprogramma Science of European Public Health. Daarnaast lever ik een bijdrage aan het onderwijs door masterstudenten te begeleiden bij onderzoek op mijn terrein.

\section{Onderzoekslijnen}

Ik wil nu het onderzoek bespreken. Ik heb mijn leerstoel 'Tabaksontmoediging' genoemd. Dit is een wat losse vertaling van 'tobacco control research', zoals het in het Engels heet. ${ }^{31}$ Laat ik een poging doen om het veld te definiëren. De WHO (2003) definieert tobacco control als: "een reeks van strategieën die ten doel hebben om de gezondheid van de bevolking te verbeteren door de consumptie van tabaksproducten en de blootstelling aan tabaksrook te elimineren of te verminderen." Ze voegt er aan toe dat het gaat om "strategieën die gericht zijn op het verminderen van het aanbod van tabak, van de vraag naar tabak en van de schade door tabaksproducten". Een goede werkdefinitie van tabaksontmoedigingsonderzoek is dan: "Wetenschappelijk onderzoek naar de effectiviteit en werking van strategieën om het aanbod van, de vraag naar en de schade door tabaksproducten te verminderen teneinde de gezondheid van de bevolking te verbeteren".32

De aanleiding voor deze leerstoel was de wens om tabaksonderzoek vanuit onderzoeksschool CAPHRI nationaal en internationaal beter te profileren. CAPHRI wás al sterk in onderzoek naar individuele stoppenmet-roken interventies en rookpreventieprogramma's. Ik hoop hier nu een nieuwe traditie aan toe te kunnen voegen, namelijk die van

31 Wij vertalen tobacco control doorgaans als 'tabaksontmoediging' en niet als 'tabaksbestrijding', wat eigenlijk een betere vertaling is van de Engelse term. De term 'tabaksontmoediging' reflecteert hoe er in Nederland tegen de problematiek wordt aangekeken: roken is niet iets dat je te vuur en te zwaard moet bestrijden; je moet het ontmoedigen. Om de knuppel niet te zeer in het hoenderhok te gooien heb ik besloten om de politiek correctere termen 'tabaksontmoediging' en 'tabaksbeleid' te gebruiken.

32 Deze definitie sluit onderzoek dat niet bijdraagt aan het gezondheidsdoel feitelijk uit en heeft daardoor een normatief karakter (Mair \& Kierans, 2007). Dit schept duidelijkheid over de focus, maar kan tevens de verdenking van partijdigheid en vooringenomenheid wekken. De oorzaak voor deze lastige situatie is de sterke polarisering van 'tabaksonderzoek': het is voor of tegen de tabaksindustrie, een middenweg lijkt niet (meer) mogelijk. Uiteindelijk gaat het er natuurlijk om dat onderzoek de wetenschappelijk toets der kritiek kan doorstaat en niet de vraag of het normatief 'goed' onderzoek is. 
onderzoek naar populatie-interventies. Daarmee ga ik het mezelf niet makkelijk maken. Er wordt wel gezegd dat er sprake is van een zogenaamde 'inverse evidence law': we weten het minste over de interventies die de meeste kans hebben om op grote schaal gezondheid te beïnvloeden (Ogilvie et al., 2005). Kleinschalige interventies die zich op individuen richten zijn veel beter onderzocht, want die lenen zich prima voor robuust, relatief makkelijk uit te voeren onderzoek in de traditie van randomized clinical trials (RCT).33 Populatiebrede interventies zijn echter veel lastiger te onderzoeken. Toch is dat wel mogelijk. Ik onderscheid drie lijnen van onderzoek waar ik mij in de komende jaren op wil gaan richten.

\section{Effecten van maatregelen op individuele rokers}

De eerste onderzoekslijn is psychologisch onderzoek naar de effectiviteit van tabaksbeleid op rokers. Dit is lastig onderzoek. Een campagne of nieuwe wetgeving gebeurt nooit geïsoleerd. De onderzoekscontext is veel 'rommeliger' dan het laboratorium (Chapman, 1993). In plaats van harde experimentele manipulaties moeten we het doen met indirect bewijs, zoals een verband tussen zelfgerapporteerde blootstelling aan een interventie en verandering in attitude- of gedrag. Bij gebrek aan de mogelijkheid om een echt experiment op te zetten, is een goed alternatief het natuurlijke experiment, waarbij maatregelen die in het ene land worden ingevoerd vergeleken worden met andere landen die de maatregel niet invoeren. Dit is precies de opzet van het ITC onderzoek waarbinnen het meeste werk binnen deze onderzoekslijn plaatsvindt. ITC staat voor International Tobacco Control Policy Evaluation Project. ITC is een wereldwijd onderzoek waarbij representatieve panels van rokers uit verschillende landen (in Europa zijn dat er nu 5, wereldwijd 20) op een gestandaardiseerde manier over meerdere jaren worden gevolgd (Fong et al., 2006). Het ITC onderzoek is momenteel een van de belangrijkste onderzoekprojecten binnen het internationale veld van Tobacco Control Research en ik ben dan ook heel blij dat wij hieraan deelnemen. Wij

33 Ik heb zelf altijd veel van dit type experimenteel onderzoek gedaan en heb daar altijd enorm veel plezier aan beleefd en veel van geleerd (zie bijvoorbeeld Crone et al., 2003; Roozen et al., 2006; Willemsen et al., 1998; Willemsen et al., 2006; Maingay \& Willemsen, 2002; Willemsen et al, 1999). Onderzoek naar stigmatisering van rokers is een mooi voorbeeld van onderzoek dat niet tot 'mainstream' tobacco control research behoort in de zin dat het op voorhand onduidelijk is of en zo ja hoe resultaten zullen bijdragen aan gezondheidsdoelen (Mair \& Kierans, 2007). Stigmatisering van rokers is dan ook nog weinig onderzocht.

35 Klasien Horstman pleitte vorig jaar in haar oratie aan deze universiteit voor meer bottom up werken en dialoog met burgers (Horstman, 2010). Kennis over wat werkt is niet voldoende om maatregelen en interventies succesvol in de praktijk te laten landen. Interactie met de maatschappij is cruciaal en het 
participeren sinds 2008 met één promovendus, Gera Nagelhout, en ik heb momenteel twee aanvragen lopen voor subsidie waarmee hopelijk nog twee andere promovendi kunnen worden aangesteld.

Ook naar de voorwaarden waaronder maatregelen goed zullen 'landen' in de samenleving, zonder al te veel ongewenste bijeffecten zoals stigmatisering van rokers, is meer onderzoek nodig. Ik heb met Arjan Bos van de faculteit Psychologie en Neurowetenschappen publicaties over dit onderwerp in voorbereiding en ga met mijn promovendus Gera Nagelhout en met een student onze ITC data op dit punt analyseren.34 Hierbij lijkt belangrijk dat het initiatief voor rookbeperkende maatregelen niet alleen vanuit de overheid komt, maar breed gedragen wordt door burgers. De basis voor verandering ligt immers bij burgers die zich bijvoorbeeld zorgen maken om blootstelling van zichzelf of van hun kinderen aan tabaksrook. Ik hoop met professor Klasien Horstman van de vakgroep Gezondheidsethiek en Wijsbegeerte te onderzoeken hoe wij burgers op lokaal niveau meer kunnen betrekken bij tabaksontmoediging. ${ }^{35}$

\section{Effecten van maatregelen op populaties}

De tweede onderzoekslijn betreft meer sociologisch getint onderzoek naar effecten van tabaksbeleid op populaties. De eenheid van analyse is hier de populatie en niet langer het individu. Een probleem is dat dit onderzoek vaak zonder passend theoretisch kader wordt uitgevoerd. Hierdoor is er minder sprake van een systematische kennisopbouw dan we zouden willen. Op dit gebied is nog echt pionierswerk te verrichten. Ik hoop met mijn macro-model voor tabaksontmoediging (het vliegwiel) een bijdrage te kunnen leveren aan het opvullen van deze leemte. Er zijn allerlei causale relaties tussen de bolletjes in het model te bedenken die we kunnen onderzoeken. Naar deze relaties is nog verbluffend weinig onderzoek gedaan. Ik heb al duidelijk gemaakt aan de hand van de theorie van Geoffrey Rose, dat de sociale norm een belangrijke populatiefactor lijkt. We zagen ook dat de industrie dit zo inschat. Het staat bovendien centraal in succesvolle Canadese en Californische geïntegreerde modellen van tabaksontmoediging. ${ }^{36}$ Maar welke evidentie is er nu eigenlijk voor het belang van de sociale norm? $\mathrm{Er}$ is nog weinig onderzoek gedaan om uit te zoeken of sociale normen in de populatie rechtstreeks door maatregelen of campagnes worden

36 Zie voor de Californische ervaring California Department of Health Services (1998) en een recent supplement bij het tijdschrift Tobacco Control (Roeseler \& Burns, 2010). 
beïnvloed en hoe de sociale norm effect heeft op tabaksconsumptie. We weten bijvoorbeeld dat in Californië het percentage mensen dat roken niet tolereert flink is toegenomen (Gilpin et al., 2004). Dit kan erop duiden dat de Californische aanpak inderdaad maatschappelijke normen over roken heeft veranderd. Maar dit kan ook het gevolg zijn van het afgenomen aantal rokers. $37 \mathrm{lk}$ hoop hier in toekomstig onderzoek meer over te weten te komen. Een eerste stap ga ik binnenkort met een student zetten. Zij gaat analyses uitvoeren op bestaande Europese datasets waarin een aantal van deze variabelen zijn gemeten.

Ander onderzoek binnen deze lijn is het monitoren van trends in het roken in Nederland. Hiervoor kunnen we beschikken over langlopende monitors van STIVORO met enorme databestanden. Analyses hierop leveren al jaren een constante stroom publicaties en rapporten die belangrijk zijn voor de onderbouwing van het tabaksbeleid in Nederland.

\section{Gebruik en integratie van interventies}

De derde onderzoekslijn richt zich op de vraag: "hoe kan het gebruik van individugerichte interventies worden vergroot, zodat deze interventies binnen een geïntegreerde aanpak van tabaksontmoediging bijdragen aan populatie-impact?". We weten dat de meeste rokers zonder professionele hulp stoppen. Het percentage rokers dat een effectief bewezen hulpmiddel of stopmethode gebruikte bij de laatste stoppoging, is in Nederland sinds 2002 iets gestegen, van 22\% naar 26\% (Nagelhout et al., 2010). Maar er is waarschijnlijk nog winst te boeken door meer rokers ertoe te bewegen professionele hulp te benutten. Roy Willems, een andere promovendus die ik mag begeleiden, is daarom bezig met een studie naar de psychologische determinanten van het wel of niet accepteren van hulp bij stoppen met roken. ${ }^{8}$

Dan is er nóg een interessant onderwerp waar ik mij in de aankomende jaren mee bezig zou willen houden. We weten dat laagopgeleide rokers slecht reageren op veel populatie-interventies (Frohlich \& Potvin, 2008) en dat ze meer moeite hebben met stoppen (Kotz \& West, 2009). Ik wil daarom consequent in al mijn onderzoek zogenaamde differentiële effecten van interventies op sociaal-economische groepen onderzoeken.

Ander Californisch onderzoek dat een relatie probeert te leggen tussen sociale acceptatie van het roken en populatie-interventies gaat gebuikt onder een gebrekkige operationalisatie van 'sociale acceptatie' (Alamar \& Glantz, 2006; Zhang et al, 2010).

38 Hierbij kijken we ook naar ongewenste neveneffecten van campagnes gericht op het stimuleren van rokers om meer hulp te aanvaarden. Recent onderzoek heeft namelijk laten zien dat ongeplande, spontane stoppogingen relatief effectief kunnen zijn. Campagnes gericht op het promoten van hulp bij het stoppen mogen niet ten koste van het aantal stoppogingen gaan (West \& Sohal 2006). 
Gelet op de toenemende verschillen tussen hoog- en laagopgeleiden wat betreft roken, is het wat mij betreft onethisch om dit niet te doen. Ik hoop bijvoorbeeld via een Europese onderzoeksaanvraag die wordt gecoördineerd door de vakgroep Sociale Geneeskunde van het Amsterdam Medisch Centrum, nog een AlO te kunnen financieren die de Europese ITC datasets systematisch op dit aspect gaat onderzoeken.

\section{Dankwoord}

Dan ben ik toegekomen aan dankzeggen. Intellectueel gezien heb ik het meeste te danken aan personen die fysiek gezien het verst van mij af staan. Ik heb het over collega-wetenschappers die ik eerst via de literatuur en later via congressen en workshops persoonlijk als collega en later als vriend heb leren kennen. Ik denk bijvoorbeeld aan Professor Ron Borland, van de University of Melbourne in Australië, die mij in 2006 in Washington op een congres nog "lazy buggard" noemde, omdat ik wel steeds verkondigde dat ik graag bij het ITC onderzoek wilde aansluiten, maar dit niet 1-2-3 voor elkaar kreeg. Gelukkig had ik een jaar later de subsidie toch binnen en kon ik hem weer onder ogen komen. Professor Shu-Hong Zu van de University of California en Professor Paul McDonald, University of Waterloo (Canada), zijn twee andere grote denkers waar ik het genoegen mee heb gehad enige tijd op te trekken. Ook in hen bewonder ik dat zij naar 'the bigger picture' kijken en zich niet in één van de kampen klinisch of Public Health hebben laten vangen. En verder Robert West, van het University College in London. Door Robert weet ik beter hoe ik theoretisch de impact van omgevingsinterventies op rookgedrag moet zien. Ik ben blij dat Robert sinds vorig jaar visiting professor is aan onze vakgroep. Het is geweldig hoezeer Robert zijn deskundigheid beschikbaar stelt en tijd vrijmaakt om mee te denken over hoe die 'crazy Dutchmen' met tabak aan het worstelen zijn.

Als we nu wat dichter bij huis kijken, kom ik aan personen die ik in Nederland schatplichtig ben. Tja, daar wordt het al wat moeilijker. Toch wordt er verspreid over verschillende Nederlandse universiteiten belangrijk onderzoek gedaan op deelaspecten van tabaksontmoediging. Het prettige contact en de samenwerking met collega-hoogleraren Arie Dijkstra, Rutger Engels, Reinout Wiers, Johan Mackenbach en Karien Stronks hoop ik in de toekomst voort te kunnen zetten en wellicht te verdiepen.

Als we nog wat dichterbij kijken, komen we bij mijn universiteit. Allereerst wil ik de Decaan bedanken voor het in mij gestelde vertrouwen. Verder wil ik de hoogleraren Onno van Schayck, Nanne de Vries en Hein de Vries bedanken voor het mogelijk maken van deze leerstoel. Professor 
van Schayck heeft zich zeer ingespannen voor de totstandkoming van de leerstoel en daar ben ik veel dank voor verschuldigd. Onno, je zult nu wél een tweede rookprofessor naast je moeten dulden! Er bestaat een lange en vruchtbare samenwerking tussen STIVORO en onderzoeksschool CAPHRI, vooral vanuit de onderzoeksgroep van professor Hein de Vries. Ik wil Hein danken voor zijn consequent vertrouwen in mij. Hein heeft toch wat in mij gezien, toen hij mij in 1989 als onderzoeksassistent aannam en anderhalfjaar later vroeg voor een promotieonderzoek. En het was ook weer Hein de Vries die met het idee voor deze leerstoel op de proppen kwam. Hein, ik heb tijdens het schrijven van mijn oratie en het steeds maar weer schrappen van geliefde passages, regelmatig aan jouw favoriete uitspraak 'kill your darlings' moeten denken. Ook daarvoor dank. Wat de rest van de vakgroep betreft: voor mij is het deels een hernieuwde kennismaking. Ik heb immers ruim 10 jaar bij deze vakgroep gewerkt, vóórdat ik naar STIVORO overstapte. Doordat ik hier maar eens per week op een kamertje zit, heb ik nog weinig gelegenheid gehad om alle voor mij nieuwe mensen goed te leren kennen. Maar dat gaat zeker nog komen!

Dan de volgende laag. Dat is STIVORO. Toen ik in 1997 gevraagd werd om het wetenschappelijk onderzoek inhoud te komen geven, nam ik me voor om een andere baan te zoeken, als het roken niet binnen een paar jaar zou afnemen. Zo gedreven en idealistisch was ik toen inmiddels geworden. Die eerste periode was achteraf gezien wel de gouden periode van STIVORO, gekenmerkt door een constante groei van de organisatie en relatief grote campagnebudgetten waardoor er enkele grootschalige stopcampagnes konden worden gevoerd. Gelukkig daalde het roken in de eerste jaren dat ik bij STIVORO werkte flink en ben ik maar bij STIVORO gebleven. Ik heb binnen STIVORO langzaam maar gestaag gewerkt aan het uitbouwen van de wetenschappelijke basis van de organisatie en van de onderzoekscapaciteit. Toen ik kwam was ik de enige onderzoeker, nu heeft STIVORO een aparte afdeling die wij Kennis en Implementatie noemen, met 14 specialisten en onderzoekers. Ik ben blij dat Dewi Segaar het management van mij heeft overgenomen zodat ik mij sinds kort echt vooral met inhoud en wetenschappelijk onderzoek mag bezighouden om zo de nationale en international expertiserol van STIVORO verder te versterken. Ik ervaar dat als een ongekende luxe. STIVORO bevindt zich, door het buitengewone tabaksvriendelijke beleid van de huidige regering, momenteel echter wel in de moeilijkste periode van haar bestaan en ik wil mijn respect uitspreken voor de bijzonder moedige manier waarop Lies van Gennip als directeur vecht voor het 
voortbestaan van STIVORO.

En dan komen we tot slot bij de kern: mijn familie en mijn gezin. Ik wil mijn moeder, Trudy, bedanken voor haar betrokkenheid door de jaren heen. Je hebt mij altijd gesteund in alles wat ik doe. Ik wil hier ook Ton, mijn vader, gedenken, die veel te vroeg uit het leven is gestapt en niets heeft meegekregen van mijn mooie carrière. Hij heeft nooit geweten dat ik in zijn voetsporen trad door psychologie te gaan studeren. Bij alles wat ik daarna bereikte heb ik steeds het gevoel gehad dat ik het ook voor hem deed. Peter, groot broertje, wij hebben samen als kind veel lief en leed gedeeld. En dan wil ik, tot slot, natuurlijk ook Jacqueline, Emma en Julia bedanken, eigenlijk vooral voor het geduld met mij. Een nadeel van een leerstoel ver weg van mijn woonplaats Leiden is dat ik minder thuis ben. Dat hebben jullie gemerkt. Dinsdag geen verhaaltje lezen met Julia, want dan zit ik weer in Maastricht. En twee avonden minder per week dat ik jullie kan verwennen met mijn kookkunsten. Toen ik thuis net bekend had gemaakt dat ik misschien wel professor zou worden, waren jullie ontzettend trots. Jacqueline ging direct een lijstje maken van mensen die ze wilde uitnodigen. Maar jullie hebben het af en toe ook te verduren gehad met mij en mijn werk. $U$ moet weten dat ik altijd een neiging heb gehad tot afwezigheid, in gedachten verzonken zijn. Nu kan ik de kinderen uitleggen dat dit normaal is voor een professor. Echte professors zijn altijd wat verstrooid. Maar Jacqueline trapt daar natuurlijk niet in. Mijn excuus dat het geen werk is maar hobby helpt natuurlijk óók niet. Jacqueline, bedankt voor het mij steeds weer bij de les houden en het relativeren van waar ik mee bezig ben. Dat heb ik af en toe echt nodig. Maar nu heb ik jullie geduld lang genoeg op de proef gesteld.

Ik heb gezegd. 


\section{Literatuur}

Advocacy Institute (2007). Smoke signals: The tobacco control media handbook. Washington: Advocacy Institute.

Alamar, B., \& Glantz, S.A. (2006). Effect of increased social unacceptability of cigarette smoking on reduction in cigarette consumption. American Journal of Public Health, 97: 1359-1363.

American Psychiatric Association (APA) (1995). Diagnostic and Statistical Manual of Mental Disorders. 4th ed. (DSM-IV). Washington: American Psychiatric Association.

Andeweg, R.B., \& Irwin, G.A. (2009). Governance and politics of the Netherlands. Houndmills, Basingstoke: Palgrave Mac Millan.

Bala, M., Strzeszynski, L., \& Cahill. K. (2008). Mass media interventions for smoking cessation in adults. Cochrane Database of Systematic Reviews 2008, Issue 1. Art. No.: CDo04704. DOI: 10.1002/14651858.CDo04704.pub2

Baltesen, R., \& Rosenberg, E. (2009). Een rokende gideonsbende. NRC Weekblad, 20-26 juni, pp.19-22.

Baumeister, R.J. \& Masicampo, E.J. (2010). Conscious thought is for facilitating social and cultural interactions: how mental simulations serve the animal-culture interface. Psychological Review, 117: 945-971.

Benford, R.D., \& Snow., D.A. (2000). Framing Processes and Social Movements: An Overview and Assessment. Annual Review of Sociology, 26: 611-639.

Biener, L., Reimer, R., Wakefield, M., Szczypka, G., Rigotti, N.A., \& Connolly, G. (2006). Impact of smoking cessation aids and mass media among recent quitters. American Journal of Preventive Medicine, 30: 217-224.

Borland, R., \& Balmford, J. (2003). Understanding how mass media campaigns impact on smokers. Tobacco Control, 12 (Suppl II): ii45-ii52.

Borland, R., Young, D., Coghill, K., \& Zhang, J.Y. (2010). The tobacco use management system: analyzing tobacco control from a systems perspective. American Journal of Public Health, 100: 1229-1236. 
Bouma, J. (2001). Het rookgordijn. De macht van de Nederlandse tabaksindustrie. Amsterdam: Veen.

Brinn, M.P., Carson, K.V., Esterman, A.J., Chang, A.B., \& Smith, B.J. (2010). Mass media interventions for preventing smoking in young people. Cochrane Database of Systematic Reviews 2010, Issue 11. Art. No.: CDo01006. DOI: 10.1002/14651858.CDo01006.pub2

Britton, J. (2009). In defence of helping people stop smoking. The Lancet, 373: 703-705.

Brown, A., Moodie, C., \& Hastings, G. (2009). A longitudinal study of policy effect (smokefree legislation) on smoking norms: ITC Schotland / United Kingdom. Nicotine \& Tobacco Research, 11: 924-934.

Brug, J \& Lenthe, van F.J. (2006). De omgeving als determinant van gezond gedrag. Gedrag \& Gezondheid, 2006; 34:38-48.

Burns DM. (2000). Smoking cessation: recent indicators of what's working at a population level. In: National Cancer Institute. Population based smoking cessation: Proceedings of a conference on what works to influence cessation in the general population. Smoking and Tobacco Control Monograph No. 12. Bethesda, MD: U.S. Department of Health and Human Services, National Institutes of Health, National Cancer Institute, NIH Pub. No. 00-4892

California Department of Health Services (1998). A model for change: the California Experience in tobacco control. Los Angeles: California Department of Health Services, Tobacco Control Section.

CBO (2004). Richtlijn Behandeling van tabaksverslaving. CBO Kwaliteitsinstituut voor de Gezondheidszorg. Alphen aan den Rijn: van Zuiden Communications.

Chaiton, M.O., Cohen, J.E., \& Frank, J. (2003). Population health and the hardcore smoker: Geoffrey Rose revisited. Journal of Public Health, 29: 307-318.

Chapman, S. (1993). Unravelling gossamer with boxing gloves: problems in explaining the decline in smoking. British Medical Journal, 307: 429-432.

Chapman, S. (2007). Public health advocacy and tobacco control: Making smoking history. Oxford: Blackwell Publishing.

Chapman, S., \& Liberman, J. (2005). Ensuring smokers are adequately informed: reflections on consumer rights, manufacturer responsibilities, and policy implications. Tobacco Control, 14 (Suppl II): ii8-ii13. 
Chapman, S., \& Lupton, D. (1994) The fight for public health: principles and practice of media advocacy. London: BMJ Books, London.

Coleman, T. (2004). ABC of smoking cessation: Use of simple advice and behavioural support. British Medical Journal, 328: 397-399.

Christakis N.A., Fowler, J.H. The collective dynamics of smoking in a large social network. New England Journal of Medicine, 2008; 358: 2249-2258.

Crone, M.R., Reijneveld, S.A., Willemsen., M.C., van Leerdam, F.J.M., Spruijt, R.D., \& Hira Sing, R.A. (2003). Prevention of smoking in adolescents with lower education: A school based intervention study. Journal of Epidemiology and Community Health, 57: 675-680.

Den Exter Blokland, E.A.W., Engels, R.C.M.E., Hale III, W.W., Meeus, W., \& Willemsen, M.C. (2004). Lifetime parental smoking history and cessation and early adolescent smoking behavior. Preventive Medicine, 38, 359-368.

De Vries, H., Backbier, E., Dijkstra, M., van Breukelen, G., Parcel., G., \& Kok., G. (1994). A Dutch social influence smoking prevention approach for vocational school students. Health Education Research, 9, 365-374.

Dijkstra, M. (1995). Development, implementation and evaluation of two Dutch smoking prevention programs. [proefschrift]. Maastricht: Universiteit van Maastricht.

Fong, G.T., Cummings, K.M., \& Shopland, D.R. (2006). Building the evidence base for effective tobacco control policies: the International Tobacco Control Policy Evaluation Project (the ITC Project). Tobacco Control, 15 (Suppl III):iii1-iii2.

Fox, B.J. (2005). Framing tobacco control efforts within an ethical context. Tobacco Control, 14 (Suppl II): ii38-ii44.

Frohlich, K. (2008). Is tobacco use a disease? Canadian Medical Association Journal, 179: 880-882.

Frohlich, K.L., \& Potvin, L. (2008). The inequality paradox. The population approach and vulnerable populations. American Journal of Public Health, 98: 216-221.

Gallet, C. \& List, J. (2003). Cigarette demand: a meta-analysis of elasticities. Health Economy, 12: $821-835$. 
Gilpin, E.A., Lee, L., \& Pierce, J.P. (2004). Changes in population attitudes about where smoking should not be allowed: California versus the rest of the USA. Tobacco Control, 13: $38-44$.

Glantz, S.A. (1996). Preventing tobacco use: The youth access trap (editorial). American Journal of Public Health, 96: 156-159.

Glantz, S.A., \& Balbach, E.D. (2000). Tobacco war: Inside the California battles. Berkeley: University of California Press.

Grüning T, \& Gilmore A. (2007). Germany: tobacco industry still dictates policy. Tobacco Control, 16: 2 .

Hammond, D., Fong, G.T., Zanna, M.P., Thrasher, J.F., \& Borland, R. (2006). Tobacco denormalization and industry beliefs among smokers form four countries. American Journal of Preventive Medicine, 31: 225-232.

Hill D. (1999). Why we should tackle adult smoking first. Tobacco Control, 8: 333-335.

Hopkins, D.P., Briss, P.A., Ricard, C.J., Husten, C.G., Garande-Kulis, V.G., Fielding, J.E., Alao, M.O., McKenna, J.W., Sharp, D.J., Harris, J.R., Woollery, T.A., \& Harris, K.W. (2001). Reviews of evidence regarding interventions to reduce tobacco use and exposure to environmental tobacco smoke. American Journal of Preventive Medicine, 20 (Suppl 2), 16-66.

Horstman, K. (2010). Dikke kinderen, uitgebluste werknemers en vreemde virussen. Filosofie van de publieke gezondheidszorg in de 21e eeuw [inaugurele rede]. Maastricht: Maastricht University.

Hosking, W., Borland, R., et al. (2009). The effects of smoking norms and attitudes on quitting intentions in Malaysia, Thailand and four Western nations: A cross-cultural comparison. Psychology and Health, 24: 95-107.

Hyland, A., Vena, C., Bauer, J. et al. (2003). Cigarette smoking-attributable morbidity - United States, 2000. Morbidity and Mortality Weekly Report, 52: 842-844.

IGZ (2010). De staat van de gezondheidszorg: Meer effect mogelijk van publieke gezondheidszorg. Utrecht: Inspectie van de Gezondheidszorg.

ITC Project (2010). ITC Netherlands National Report. Waterloo. The Hague: University of Waterloo, STIVORO. 
Joossens, L., \& Raw, M. (2007). Progress in tobacco control in 30 European countries, 20052007. Bern: Swiss Cancer League.

Kok, G., Schaalma, H., \& Brug, J. (2000). Planmatige gezondheidsvoorlichting: een inleiding. In J. Brug, J. Schaalma, G. Kok., R.M. Meertens, en H.T. Van der Molen (red.). Gezondheidsvoorlichting en gedragsverandering: Een planmatige aanpak. Assen: Van Gorcum.

Kotz, D., \& West, R. (2009). Explaining the social gradient in smoking cessation: it's not in the trying, but in the succeeding. Tobacco Control, 18, 43-6.

Lavack, A.M. (1999). De-normalization of tobacco in Canada. Social Marketing Quarterly, 5: $82-885$.

Levy, D.T., Cummings, K.M., \& Hyland, H. (2000). A simulation of the effects of youth initiation policies on overall cigarette use. American Journal of Public Health, 90: 1311-1314.

Levy, D.T., Mabry, P.L., Graham, A.L., Orleans, T., \& Abrams, D.B. (2010). Exploring scenarios to dramatically reduce smoking prevalence: A simulation model of the three-part cessation process. American Journal of Public Health, 100: 1253-1259.

Mackenbach, J. (2009). Politics is nothing but medicine at a larger scale: reflections on public health's biggest idea. Journal of Epidemiology and Community Health, 63: 181-184.

Maingay, R., \& Willemsen, M.C. (2002). Effecten van een 3-jarig multicomponenten school interventie op beginnen met roken bij adolescenten; analyse van de dataset ESFA Nederland 1998 - 2001. Den Haag: STIVORO.

Mair, M. \& Kierand, C. (2007). Critical reflections on the field of tobacco research: The role of tobacco control in defining the tobacco research agenda. Critical Public Health, 17: 103-112.

Marmor, T.R., \& Liberman, E.S. (2004). Tobacco control in comparative perspective: Eight nations in search of an explanation. In E.A. Feldman \& R. Bayer. (Eds.). Unfiltered: Conflicts over tobacco policy and public health. Cambridge, Massachusetts: Harvard University Press.

McKinlay, J.B., \& Marceau, L.D. (2000). Upstream healthy public healthy policy: lessons from the battle of tobacco. International Journal of Health Services, 30: 49-69.

Mudde, A.N., \& de Vries, H. (1997). The reach and effectiveness of a national mass medialed smoking cessation campaign in the Netherlands. American Journal of Public Health, 89: 346-350. 
Myers, M.L. (1999). Adults versus teenagers: a false dilemma and a dangerous choice. Tobacco Control, 8: 336-338.

National Cancer Institute (2007). Greater than the sum: systems thinking in Tobacco Control. Smoking and Tobacco Monograph No. 18. Bethesda, MD: U.S. Department of Human Services, National Institutes of Health, National Cancer Institute, NIH Pub. No. 06-6085.

National Cancer Institute (2008). The role of the media in promoting and reducing tobacco use. Smoking and Tobacco Monograph No. 19. Bethesda, MD: U.S. Department of Human Services, National Institutes of Health, National Cancer Institute, NIH Pub. No. 06-6085.

Nagelhout, G.E., De Korte, D., Zeegers, T., van der Meer, R., \& Willemsen, M. (2010). Themapublicatie: Hulpmiddelengebruik bij stoppen met roken in Nederland, $1992-2009$. Den Haag: STIVORO.

Nagelhout, G.E., van den Putte, B.S.J.H.M. de Vries, H., \& Willemsen, M.C. (submitted). Newspaper coverage about the hospitality industry smoking ban in the Netherlands and the relationship with attitudes of smoking newspaper readers. Paper submitted.

Neuman, M., Bitton, A., \& Glantz, S. (2002). Tobacco industry strategies for influencing European Community tobacco advertising legislation. The Lancet, 359: 1323-1330.

Niederdeppe, J., Farrelly, M.C., \& Wenter, D. (2007). Media advocacy, tobacco control policy change and teen smoking in Florida. Tobacco Control, 16: 47-52.

Ogilvie, D., Egan, M., Hamilton, V., \& Petticrew, M. (2005). Systematic reviews of health effects of social interventions: 2. Best available evidence: how low should we go? Journal Epidemiology and Community Health, 59: 886-892.

Otten, R., (2007). Waiting to inhale: Psychosocial factors $f$ smoking in adolescents with and without asthma. Nijmegen: Radboud University [academisch proefschrift].

Pelsmacker, P de. (2010). Wie is bang voor fear appeals? Angstprikkels in sociale marketing. Amsterdam: SWOCC publicatie nr. 53 .

Pollay, R.W. (2007). More than meets the eye: on the importance of retail cigarette merchandising. Tobacco Control, 16:270-274.

PriceWaterhouseCoopers (PWC) (2010). Prevention pays. Amsterdam: PriceWaterhouseCoopers. 
Reid, D.J., Killoran, A.J., McNeill, A.D., \& Chambers, J.S. (1992). Choosing the most effective health promotion options for reducing a nation's smoking prevalence. Tobacco Control, 1: $185-197$

Roeseler A, \& Burns, D. (2010). The quarter that changed the world. Tobacco Control, 19 (Suppl 1): i3-i15.

Rose G. (1992). The Strategy of Preventive Medicine. Oxford: University Press.

Roozen, H.G., van Beers, S.E.C., Weevers, H-J.A., Breteler, M.H.M., Willemsen, M.C., Postumus, P.E., \& Kerkhof, A.J.F.M. (2006). Effects on smoking cessation: Naltrexone combined with a cognitive behavioural treatment based on the Community Reinforcement Approach. Substance Use and Misuse, 41, 45-60.

Smith, K. E., Fooks, G., Collin, J., Weishaar, H., Mandal, S., \& Gilmore, A. B. (2010). “Working the system" - British American Tobacco's influence on the European Union Treaty and its implications for policy: an analysis of internal tobacco industry documents. PLoS Medicine, 7 (1), e1000202.

Smith, K.E., Gilmore, A.B., Fooks, G., Collin, J., \& Weishaar, H. (2009). Tobacco industry attempts to undermine Article 5.3 and the 'good governance' trap. Tobacco Control, 18: 509-511.

Sowden A.J. \& Arblaster, L. (2003). Mass media interventions for preventing smoking in young people. The Cochrane Library, Issue 1, 2003. Oxford: Update Software.

STIVORO (2010). Van onderop en van bovenaf. De toekomst van tabaksontmoediging in Nederland 2011 - 2020. Den Haag: STIVORO.

Strünck C, Grüning T, \& Gilmore A. (2008). Puffing away? Politics of tobacco control in Germany. German Politics, 17: 140-164

Studlar, D.T. (2002). Tobacco Control: Comparative politics in the United States and Canada. Peterborough, Ontario: Broadview Press.

Taioli, E., \& Wynder, E.L. (1991). Effect of the age at which smoking begins on frequency of smoking in adulthood. New England Journal of Medicine, 325: 968-969.

Thomas, R. \& Perera, R. (2006). School-based programs for preventing smoking. Cochrane Database of Systematic Reviews. Oxford: Update Software. 
Thyrian, J.R., \& John, U. (2007). Population impact: Definition, calculation and its use in prevention science in the example of tobacco smoking reduction. Health Policy, 28: 348-356.

Tiemeijer WL, Thomas CA, \& Prast HM (Red.) (2009). De menselijke beslisser: Over de psychologie van keuze en gedrag.. Amsterdam: Amsterdam University Press.

Timmers, R., \& van der Wijst, P. (2007). Images as anti-smoking fear appeals: the effects of emotion on the persuasion process. Information Design Journal, 15: 21-36.

U.S. Department of Health and Human Services (USDHHS) (2010). How Tobacco Smoke Causes

Disease: The Biology and Behavioral Basis for Smoking-Attributable Disease. A Report of the Surgeon General. Public Health Service Office of the Surgeon General, Rockville, MD.

Van den Bos, A. (2010). From controvery to courtesy: Tobacco industry's tactics to prevent workplace smoking restrictions in The Netherlands. Vrije Universiteit: Master thesis.

Van den Putte, S.J.H.M., Yzer, M.C., ten Berg, B.M., \& Steeveld, R.M.A. (2005). Nederland Start Met Stoppen / Nederland Gaat Door Met Stoppen. Evaluatie van de STIVORO campagnes rondom de jaarwisseling 2003-2004. Amsterdam.: ASCOR.

Van der Lucht, F., \& Polder, J. (2010). Van gezond naar beter: Kernrapport Volksgezondheid Toekomst Verkenning 2010. Bilthoven: RIVM.

Van der Wilk, E.A., Melse, J.M., den Broeder, J.M., Achterberg, P.W. (2007). Leren van de buren: beleid publieke gezondheid international bezien: roken, alcohol, overgewicht, depressie, gezondheidsachterstand, jeugd screening. Bilthoven: RIVM.

Van Gelder, B., Over, E., Hoogenveen, R., Willemsen, M., Verweij, A., Droomers, M., \& Feenstra, T.. (2011) Modeling smoking in relation to educational level for adolescents: effects and costs of two tobacco control programs for lower educational levels. Paper submitted.

Wakefield, M.A., Loken, B., \& Hornik, R.C. (2010). Use of mass media campaigns to change health behaviour. The Lancet, 376: 1261-1271.

Walgrave, S., \& Van Aelst, P. (2006). The contingency of the mass-media's political agenda setting power: Toward a preliminary theory. Journal of Communication, 56: 88-109.

Wallack, L., \& Dorfman, L. (1996). Media advocacy: a strategy for advancing and promoting health. Health Education Quarterly, 23: 293-317. 
Warner, K.E. (2006). Tobacco policy research: Insights and contributions to public health policy. In K.E. Warner (Ed). Tobacco Control Policy. San Fransisco: Jossey-Bass.

Warner, K.E. (2008). Smoking cessation treatment in a public-health context. The Lancet, 371: $1976-1978$.

West, R. (2007). Theory of addiction. Oxford: Blackwell Publishing.

West, R., \& Sohal, T. (2006). 'Catastrophic' pathways to smoking cessation: findings from a national study. British Medical Journal, 332: 458-460.

Westerik, H., \& van der Rijt, G (2001). De Millenniumcampagne Stoppen met roken 2000: Evaluatie van een campagne onder Nederlandse rokers. Nijmegen: Radboud University.

White, V., Tan., Wakefield, M., \& Hill, D. (2003). Do adult focused anti-smoking cessation campaigns have an impact on adolescents? The case of the Australian National Tobacco Campaigns. Tobacco Control, 12 (Suppl. 2): ii23-ii29.

Wiehe, S.E., Garrison, M.M., Christakis, D.A., Ebel, B.E., \& Rivara, F.P. (2005). A systematic review of school-based smoking prevention trials with long-term follow-up. Journal of Adolescent Health, 36: 162-169.

Willemsen, M.C. (2005). Effectiviteit van overheidsmaatregelen en voorlichtingscampagnes. In: K. Knol, C. Hilvering, D.J.Th. Wagener, \& M.C.Willemsen (Red.). Tabaksgebruik: gevolgen en bestrijding, pp. 334-361. Utrecht: Lemma.

Willemsen, M.C. (2006). Rokers onder vuur? Invloed van de gewijzigde tabakswet op rokers, met speciale aandacht voor verschillen tussen sociaal-economische klassen. Den Haag: STIVORO.

Willemsen MC. (2010). Tabaksverslaving: de impact van gezondheidsvoorlichting en hulpverlening op de totale populatie rokers. Psychologie \& Gezondheid, 38:119-130.

Willemsen, M.C., De Vries, H., \& Genders, R. (1998). Long-term effectiveness of two Dutch worksite smoking cessation programs. Health Education \& Behavior, 25, 418-435.

Willemsen, M.C., \& de Zwart, W.M. (1999). The effectiveness of policy and health education strategies for reducing adolescent smoking: a review of the evidence. Journal of Adolescence, 22, 587-599. 
Willemsen, M.C., de Zwart, W.M., \& Mooy, J.M. (1998). Effectiviteit van overheidsmaatregelen om het tabaksgebruik terug te dringen. In: E.W. Roscam Abbing (Ed). Tabaksontmoedigingsbeleid: Gezondheidseffectrapportage. Utrecht: Netherlands School of Public Health.

Willemsen, M.C., Spruijt, R., \& Kramer, R. (1999). Mission Incredible: Een niet-roken afspraak voor leerlingen in de eerste klassen van het voortgezet onderwijs. Tijdschrift voor Jeugdgezondheidszorg, 31 (3), 33-36.

Willemsen, M.C., Wagena, E.J., \& van Schayck, C.P. (2003). De effectiviteit van stoppen-metrokenmethoden die in Nederland beschikbaar zijn: een systematische review op basis van Cochrane-gegevens. Nederlands Tijdschrift voor Geneeskunde, 147, 922-927.

Willemsen, M.C., Wiebing, M., van Emst, A., \& Zeeman, G. (2006). Helping smokers to decide on the use of efficacious smoking cessation methods: a randomized controlled trial of a decision aid. Addiction, 101, 441-449.

World Bank (1999). Curbing the Epidemic: governments and the economics of tobacco control. Washington: The World Bank.

World Health Organization (WHO) (1992). International statistical classification of diseases and related health problems. 10th ed. Genève: WHO.

World Health Organization (WHO) (2003). WHO Framework Convention on Tobacco Control. Genève: WHO.

World Health Organization (WHO). (2007). The European Tobacco Control Report 2007. Genève: WHO.

World Health Organization (WHO) (2008). Tobacco industry interference with tobacco control. Genève: WHO.

Zhu, S-H. (2006). Increasing cessation in the population: quit attempts versus successful quit attempts. Presentatie op 13th World Conference on Tobacco or Health. Washington, DC, July 12-15, 2006.

Zhang, X., Cowling, D.W., \& Tang, H. (2010). The impact of social norm change strategies on smokers' quitting behaviours. Tobacco Control, 19 (Suppl 1): i51-i55. 
